\title{
Sønderjyllands største gods
}

Søgård-Gråsten i Ahlefeldternes tid

\section{af Carsten Porskrog Rasmussen}

Fra omkring 1500 til 1725 var Søgård centrum for Sønderjyllands største gods, der samtidig var ét af de betydeligste i hele det danske rige. I løbet af denne periode skiftede godset karakter, idet der blev oprettet en række hovedgårde, hvoraf Gråsten blev den mest berømte. Lektor, lic.phil. Carsten Porskrog Rasmussen, Aabenraa, kaster her nyt lys over godsets udvikling, og viser, hvordan de gradvise ændringer i godsstrukturen fik afgørende betydning for området og dets befolkning.

J.P. Trap: Danmark (5. udgave) er et værk, der på mange måder gør det lettere at beskæftige sig med dansk historie. Det gælder ikke mindst de sønderjyske bind, der fik lov til at svulme op til et helt andet omfang end de kongerigske. Medvirkende hertil er deres lange række af artikler om ejendomsforhold i ældre tid. Med uhyre flid er jordebøger, godsbeskrivelser, regnskaber og adkomstbreve pløjet igennem og sammenfattet $\mathrm{i}$ historiske oversigter for de enkelte sogne, som hovedregel fra reformationstiden op til 1800-tallet. Heraf fremgår, hvor mange og hvor store gårde der hørte under forskellige amter, godser og stiftelser. Alle bare lidt større eller mere specielle gårde får desuden en særligt omfattende beskrivelse. Dette enorme arbejde er udført af Peter Kr. Iversen og Johan Hvidtfeldt.

Godt 30 af de mange artikler handler om det engang så imponerende storgods, Søgård-Gråsten, og dets hovedgårde og fæstegods. Tilsammen giver de det bedste eksisterende billede af et mægtigt gods, der ændrede skikkelse fra 1500-tallet til 1700-tallet, først og fremmest $\mathrm{i}$ kraft af bondegårdsnedlæggelser og en række herregårdsoprettelser. Denne artikel vil prøve at give et mere samlet billede af denne udvikling. Ejerhistorien er derimod behandlet ret grundigt af Mikael Venge og Poul Andersen. ${ }^{1}$

\section{Slottet og herredet}

Sidst i 1400-tallet var Søgård det næststørste adelsgods i Sønderjylland. Kun Tørning var større. ${ }^{2}$ Når netop de to godser hævede sig højt over alle andre, er det ikke tilfældigt. De havde bag sig en næsten fælles og højst usædvanlig historie, der er tæt knyttet til det urolige 1300-tal. 
I 1300-tallets første halvdel gik ikke bare den danske kongemagt, men også hertugmagten i Sønderjylland mere eller mindre i opløsning, og landet kom under de holstenske grevers herredømme. Greverne satte igen enkelte borge og områder $\mathrm{i}$ pant til deres håndgangne mænd. ${ }^{3}$ For en kort periode nærmede Danmark og Sønderjylland sig tyske tilstande, hvor den centrale kongemagt var veget for de mange store og små fyrsters og ridderes lokale herredømme.

Blandt de mægtigste af de mange holstenske borgherrer i Danmark og Sønderjylland var mændene af slægten Limbek. Omkring midten af 1300-tallet finder vi dem på Kalø i kongeriget og på Søgård, Tørning og Trøjborg i Sønderjylland. Tørning kendes som en mægtig borg fra midten af 1300-tallet og middelalderen ud. Søgård har sandsynligvis sin rod i en kongsgård i Kliplev, der nævnes i Kong Valdemars Jordebog fra ca. 1231. Selve borgen nævnes først i 1357 og er formentlig anlagt forholdsvis kort tid forinden. I 1375 lovede Limbekerne, at Søgård skulle stå åben for de holstenske grever. I 1428 aftalte Søgårds daværende ejer Benedict Ahlefeldt, at han skulle gå med greverne i krig mod kong Erik af Pommern. Til gengæld lovede de at skaffe ham Søgård igen, hvis den blev indtaget. Begge breve tyder på, at Søgård var en borg, der blev tillagt væsentlig militær betydning. ${ }^{4}$

Med Søgård og Tørning fulgte de omgivende herreder. Johannes Limbek fik allerede 1344 Lundtoft herred i pant. Omkring Tørning er forholdene lidt uklare, men senest i 1394 fik Limbekerne Gram herred i pant. I 1421 blev pantet udvidet til at omfatte også Hviding, Frøs og Kalvslund herreder. I 1460 blev Gram herred endda gjort til herrerne af Tørnings private ejendom. ${ }^{5} \mathrm{Med}$ disse pantsættelser fik herrerne på Tørning og Søgård en magt over den omgivende egn, der svarede til amtmændene på de hertugelige slotte, som f.eks. Haderslev, Aabenraa og Tønder. De fik indtægterne af selvejerbønderne, og de havde den overordnede myndighed over hele egnen.

Det var ikke enestående, at adelsmand sad som panteherrer på et slot med tilhørende herred. To forhold skiller imidlertid Tørning og Søgård ud. For det første blev selve slottene med avlsgårde og fæstegods regnet som privat ejendom. I 1357 blev det således præciseret, at Søgård ikke indgik i pantet Lundtoft herred. ${ }^{6}$ For det andet blev panterne ikke indløst $i$ mere end hundrede år, hvilket indebar, at magten over Tørninglen og Lundtoft herred blev arvelig.

Både Tørning og Søgård gik fra Limbekerne i arv til Ahlefeldterne. Det var dog to forskellige grene af denne mægtige holstenske slægt, der overtog de to nordslesvigske storgodser. Den første af slægten på Søgård var Hr. Claus Ahlefeldt, der formentlig havde giftet sig til den, idet hans kone Anna Pogwisch var en datterdatter af den sidste Limbek på gården. Claus Ahlefeldt var ejer af Søgård senest fra 1398. Han faldt under kampene i Ditmarsken 1404. Han efterfulgtes på Søgård af sin søn Benedict og han igen af sin søn Claus. 


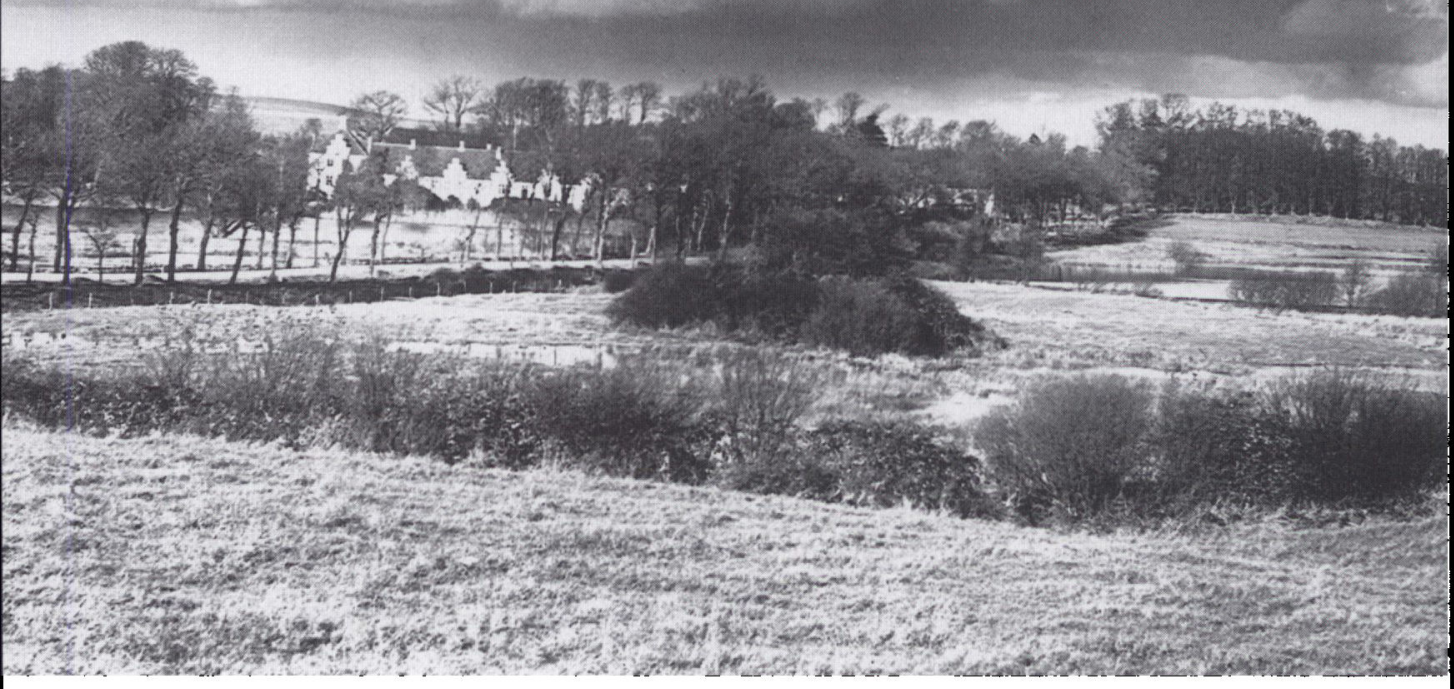

Sogård set fra syd. I forgrunden ses voldstedet af det middelalderlige Sogård. Det eneste, der er tilhage, er en ret lav ringvold. der adskilte en indre og ydre voldgrav. Selve borgen la $i$ det lave omrade inden for volden. I baggrunden det senere Sogaird, der blev bygget pd soens nordbred i 1830'erne, og som fik de karakteristiske kamtakkede kviste 1858-60. Huset er desvarre ombygget til ukendelighed efter statens overtagelse. Foto of C. M. Lund 1928. Haderslev Museum.

Ved hans død i 1487 var endnu en Benedict Ahlefeldt klar til at tage over, men han måtte dog i første omgang dele godset med broderen Jørgen. Jørgen Ahlefeldt faldt imidlertid i slaget ved Hemmingstedt i 1500, og Søgård var atter samlet på én hånd. ${ }^{7}$

I fire generationer sad Ahlefeldterne som herrer til Søgård og panteherrer $\mathrm{i}$ Lundtoft herred. Næsten lige så længe sad en anden gren på Tørning slot og len. I 1490'erne var kong Hans og hans bror hertug Frederik imidlertid rede til at indskrænke Ahlefeldternes helt særegne magtstilling i Nordslesvig. I 1494 købte kongen Tørning slot, gods og len. Det kostede så ganske vist afståelse af bl.a. de kongelige borge Gelting og Haseldorf med store tilliggender. ${ }^{8}$ I 1498 kom turen til herrerne på Søgård. Slot og fæstegods fik de lov at beholde, men hertug Frederik indløste det gennem mere end halvandet hundrede år pantsatte Lundtoft herred, der herefter blev lagt under Tønder amt. ${ }^{9}$

Der er imidlertid ikke tvivl om, at det Lundtoft herred, Ahlefeldterne leverede tilbage i 1498, var ganske anderledes, end det, Johannes Limbek hav- 
de fået overladt 154 år tidligere. Kong Valdemars Jordebog fra 1231 nævner kun lidt krongods i Lundtoft herred. I Kliplev var der en kongsgård, men hvor meget af byen, der hørte til den, er usikkert. Så var der lidt krongods i Vilsbæk, Sdr. Hostrup og "Ensted « (Stubbæk?). ${ }^{10}$ Halvandet hundrede års panteherredømme havde imidlertid gjort det muligt for Limbeker og Ahlefeldter at sætte sig på flere og flere gårde $\mathrm{i}$ herredet. Den første Ahlefeldts enke fordrev ifølge et kongeligt klagebrev fra 1409 en kongeligsindet adelsmand, Jeppe Iversen, fra gården Holbæk i Adsbøl sogn, der ligger lige på den anden side af herredsgrænsen. ${ }^{1}$ Det er meget tænkeligt, at også andre lavadelige måtte vige for de mægtige herrer og fruer på Søgård. Vi må også tro, at selvejerbønder, der følte sig trængte i de urolige tider, afgav deres gårde til Søgårds ejere.

I hvert fald var Ahlefeldternes dominans i Lundtoft herred på reformationstiden overvældende. Landsherren rådede dels over 5 fæstegårde i Holbøl sogn, som var lagt under Haderslev amt, og dels over 53 selvejergårde, der lå under Tønder amt. Af de sidstnæunte havde de $7 \mathrm{dog}$ hver to ejere og var formentlig reelt delt. Slægten Uge på Skovbølgård ejede to fæstegårde i Felsted sogn. Resten af Lundtoft herred - 178 gårde tilhørte Ahlefeldterne! De ejede alle gårde pånær tre $\mathrm{i}$ hovedgårdsognet Kliplev og nabosognet Kværs, knap tre fjerdedele af gårdene i de næstnærmeste sogne Felsted, Ensted og Holbøl og omkring halvdelen i herredets fjerneste sogne Uge og Rinkenæs. ${ }^{12}$ Det var en dominans, som intet kongerigsk storgods kunne leve op til. Nærmest kommer Gyldenstjernernes Ågård i Hanherred. ${ }^{13}$

\section{»Begge Søgårde«}

De første tre ejere af slægten Ahlefeldt havde alle efterladt sig flere sønner. Alligevel var godset forblevet udelt. Men ved Benedict Ahlefeldts død omkring 1512 gik det ikke længere. To sønner, der bar de i denne sammenhæng helt nye navne, Frantz og Gregers, kom begge til at efterlade sig slægt. De delte $\mathrm{i}$ 1535 Søgård mellem sig. Typisk for 1500-tallet skete det med en for os absurd millimeterretfærdighed. Herregårdens bygninger blev delt, så de to endte med hver at få to af de fire fløje, borgen bestod af. Også stalde og dyrkede marker blev delt mellem de to. En række "særmarker« rundt omkring, der især synes at have været græsningsarealer og skove, skulle være fælleseje. Fæstegodset blev delt, så de to brødre landsby for landsby så vidt muligt fik halvdelen af gårdene og dermed lige andel $\mathrm{i}$ både $\mathrm{i}$ magre og frugtbare egne. ${ }^{14}$ Når man overhovedet kunne dele på den måde, hang det sammen med, at godset endnu først og fremmest var en samling fæstegårde, hvor godsejeren stort set levede 


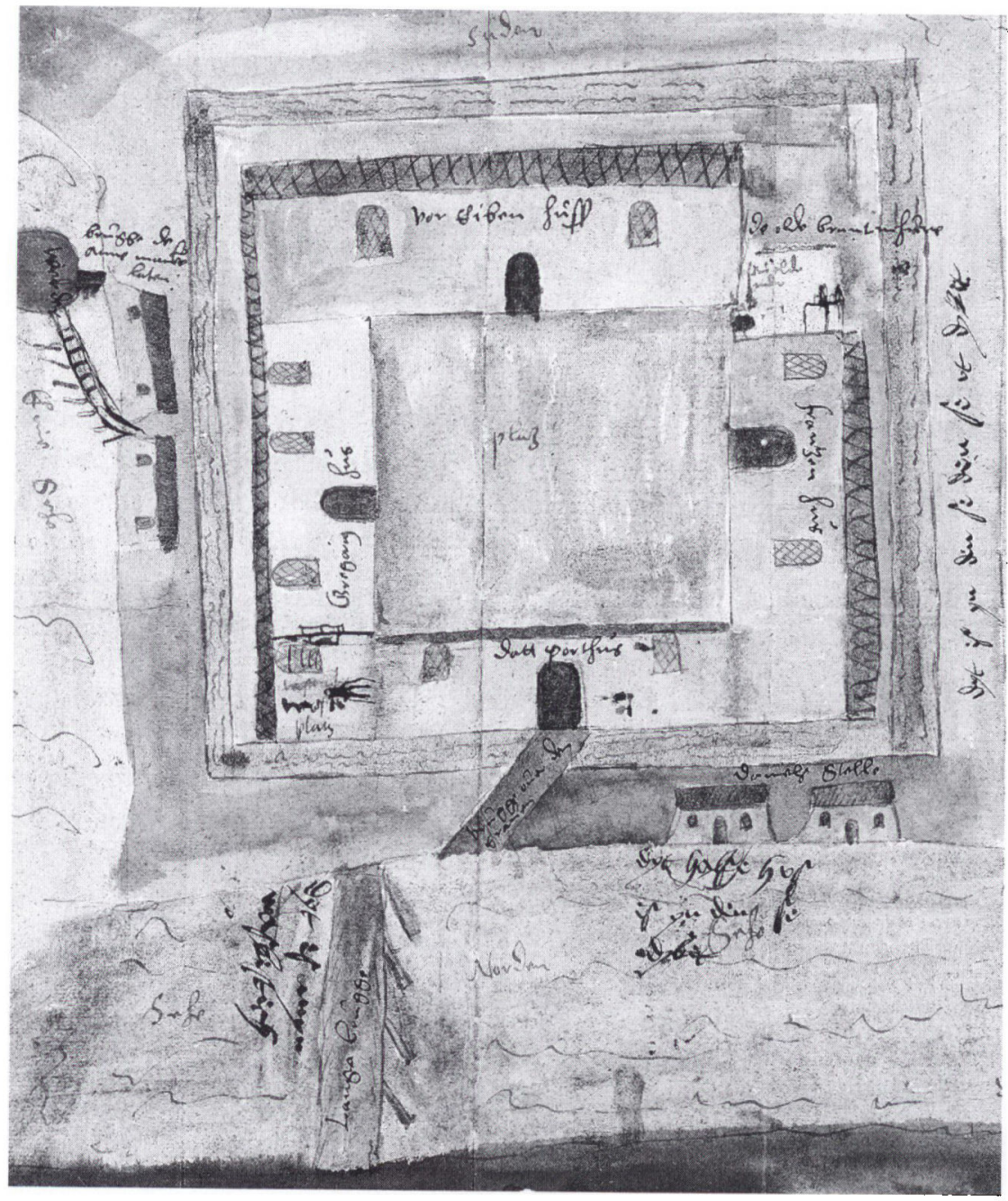

Den aldste eksisterende afbildning af Søgdrd er en tegning fra 1569, der horer til akterne fra en retssag. Tegningen har syd opad. Borgen bestod af fire floje med portflojen mod nord, og den rejste sig direkte af den omgivende voldgrav. Voldgraven var så atter omgivet af en vold til alle sider, hvorpd staldene fandtes, og uden for den bredte slotssøen sig. Mod nord, tvars over søen, strakte sig »lange brow, der var den vigtigste adgangsvej. Borgen md have mindet meget om det endnu eksisterende Spottrup $i$ Salling, der pà samme mdde har dobbelt voldgrav med en vold imellem.

Tegningen viser samtidig delingen af Segård i 1500-tallet. Vestflojen var "Frantz' hus", ostflojen "Gregers' husw, mens sydflejen var deres mors, "Fru Eibes husw. Ved en senere deling havde Gregers Ahlefeldt også fảet sydflejen, mens Frantz var tildelt portflejen mod nord. Staldene mod nord betegnes "Daniels stalde" efter Daniel Rantzau, gift med Frantz Ahlefeldts datter. Staldene i sydost horte til den anden part. Schleswig-Holsteinisches Landesarchiv. 
af de afgifter, bønderne betalte. Selve herregårdene betød kun meget lidt $\mathrm{i}$ 1400-tallet og begyndelsen af 1500 -tallet. ${ }^{15}$

Frantz og Gregers Ahlefeldt døde begge i 1559. Gregers Ahlefeldt efterfulgtes af sin enke Anna og senere af sønnen Hans. Frantz Ahlefeldt havde ingen sønner, men derimod to døtre. Af disse fik Mette Årtoft, mens Dorothea fik faderens halvdel af selve Søgård. Faderens fæstegårde fortsatte de efter alt at dømme med at dele efter samme principper, som i 1535. I hvert fald var Kværs by i 1569 delt sådan, at Mette Ahlefeldt havde fire bønder og Dorothea tre, mens Anna Ahlefeldt fortsat havde de otte fæstere i byen, hendes mand havde fået i $1535 .^{16}$

Delingen i én halvdel og to fjerdedele stod ikke ved magt, idet njomfru Mette« på Årtoft aldrig blev gift. Frantz Ahlefeldts del med det halve Søgård og Årtoft tilfaldt dermed alene Dorothea Ahlefeldt. Hun var gift to gange, forste gang med Hans Ahlefeldt til Seestermühe, anden gang med Daniel Rantzau. Hendes søn af første agteskab, Frederik Ahlefeldt, arvede godserne og sørgede for, at Ahlefeldt-navnet blev ført videre på stedet, selvom det faktisk var en fjern gren af den vidtforgrenede slægt, der tog over. Frederik Ahlefeldt efterfulgtes af sin søn af samme navn. Han blev gift med Birgitte Ahlefeldt fra grenen på den anden halvdel af Søgård. ${ }^{17}$

Denne anden halvdel gik udelt fra far til søn i fire generationer. Mændene hed skiftevis Gregers og Hans. Den sidste Hans Ahlefeldt kom i økonomiske vanskeligheder. I 1648 solgte han den østlige del af sine godser med Gråsten og Fiskbæk til hertugen af Glücksborg, mens han beholdt den øvrige del med bl.a. det halve Søgård og Ladegård. ${ }^{18}$ Ved sin død i 1663 var Hans Ahlefeldt fallit.

Hans Ahlefeldts søstersøn, den senere storkansler Frederik Ahlefeldt, havde efter sin far arvet den anden halvdel af Søgård med Årtoft og Grøngrøft. Som én af de største kreditorer overtog han nu Hans Ahlefeldts tilbageværende godser: det halve Søgård, Ladegård og Stoltelund. ${ }^{19}$ Senere samme år købte han også Gråsten og Fiskbæk tilbage fra hertugen af Glücksborg. Hele det store gods var atter forenet, og Frederik Ahlefeldt kunne kalde sig herre til "Begge Søgårde og Gråsten«. I 1670 føjede han hertil Ballegård i Ullerup sogn. Søgård var ødelagt af svenske tropper i vinteren 1643-44. Frederik Ahlefeldts far var i stedet flyttet ind på Grøngrøft. Selv valgte han imidlertid Gråsten, der havde været hans mors hjem, og det blev fra da af godskompleksets centrum.

Det enorme sønderjyske gods var storkanslerens hovedsæde, men kun én af flere besiddelser. Han giftede sig til Tranekær og det halve Langeland, som senere blev gjort til et grevskab. Selv købte han det frugtbare marskområde die Wildniss ved Glückstadt, og efter at kejseren havde gjort ham til romersk rigsgreve, købte han grevskabet Rixingen mellem Strassbourg og Nancy. 
Storkanslerens ældste søn, der som far, farfar og oldefar hed Frederik, og som var general, arvede blandt andet de sønderjyske godser, die Wildniss og grevskabet Langeland. Han føjede ca. 1705 det lille gods Skovbølgård til Søgård-Gråsten-komplekset. De gråstenske godser havde nu nået deres absolutte kulmination. De var imidlertid også tæt ved enden. Generalen, der havde arvet så store godser, efterlod en gald på 300.000 rigsdaler. Hans brodersøn mente, at det skyldtes hans »overmodige ærgærrighed efter at komme hertugen af Württemberg og andre store feltherrer lig i pragt og ødselhed«.

Generalens bror Carl arvede nu både Langeland og de sønderjyske og holstenske godser. Han føjede selv Kalundborg Ladegård til, og han blev rigets største jordbesidder, men også dets mest forgaldede mand, bl.a. fordi han overtog broderens gæld og forpligtelser til at udbetale medarvinger store summer. Ved sin død i 1722 var Carl Ahlefeldt reelt fallit. Af alle hans godser beholdt slægten alene grevskabet Langeland, der ikke hæftede for hele galden. ${ }^{20}$

Søgård-komplekset solgtes ved den største tvangsauktion i Sønderjyllands historie i 1725. Det blev da splittet op i 9 parter, der blev solgt hver for sig. Fem af de i alt 13 hovedgårde - Gråsten, Fiskbæk, Kiding, Årup og Kelstrup fik dog en ny falles ejer i hertugen af Augustenborg og udgjorde dermed stadig en statelig besiddelse. Ahlefeldternes tid var imidlertid forbi. Hvad den nærmere havde betydet for egnen mellem Aabenraa, Padborg og Gråsten skal der ses nærmere på i det følgende.

\section{Godsets omfang}

Det første overblik over Søgårds tilliggende har vi fra 1543. Det omfattede da 252 gårde. Heraf regnedes de 251 for helgårde (eller plove), mens en enkelt gård i Snogbæk i Sundeved regnedes for halvgård. De 178 gårde i Lundtoft herred udgjorde sammen med de 14 gårde $\mathrm{i}$ Tinglev og Bov sogne mod vest og de 19 gårde i Bovrup, Bojskov og Fiskbæk byer mod øst et sammenhængende gods på 211 gårde. Strøgods var kun 11 gårde længere mod vest og 29 gårde på Sundeved og Broagerland, og de fleste af disse gårde lå ikke så langt fra herregården endda. Godset var dermed enestående smukt samlet $i$ forhold til de få godser i kongeriget, der kunne måle sig med det i størrelse. ${ }^{21}$

Derfor var der heller ikke så store muligheder for at forbedre godsets arrondering, sådan som det ellers skete med de fleste kongerigske godser. I kongeriget lod Frederik II og Christian IV private godsejere købe de fleste tilbageværende selvejergårde. Det skete kun i sjældne tilfælde i hertugdømmerne. Ét af disse var i 1548, hvor Gregers Ahlefeldt mageskiftede med hertug Hans den 


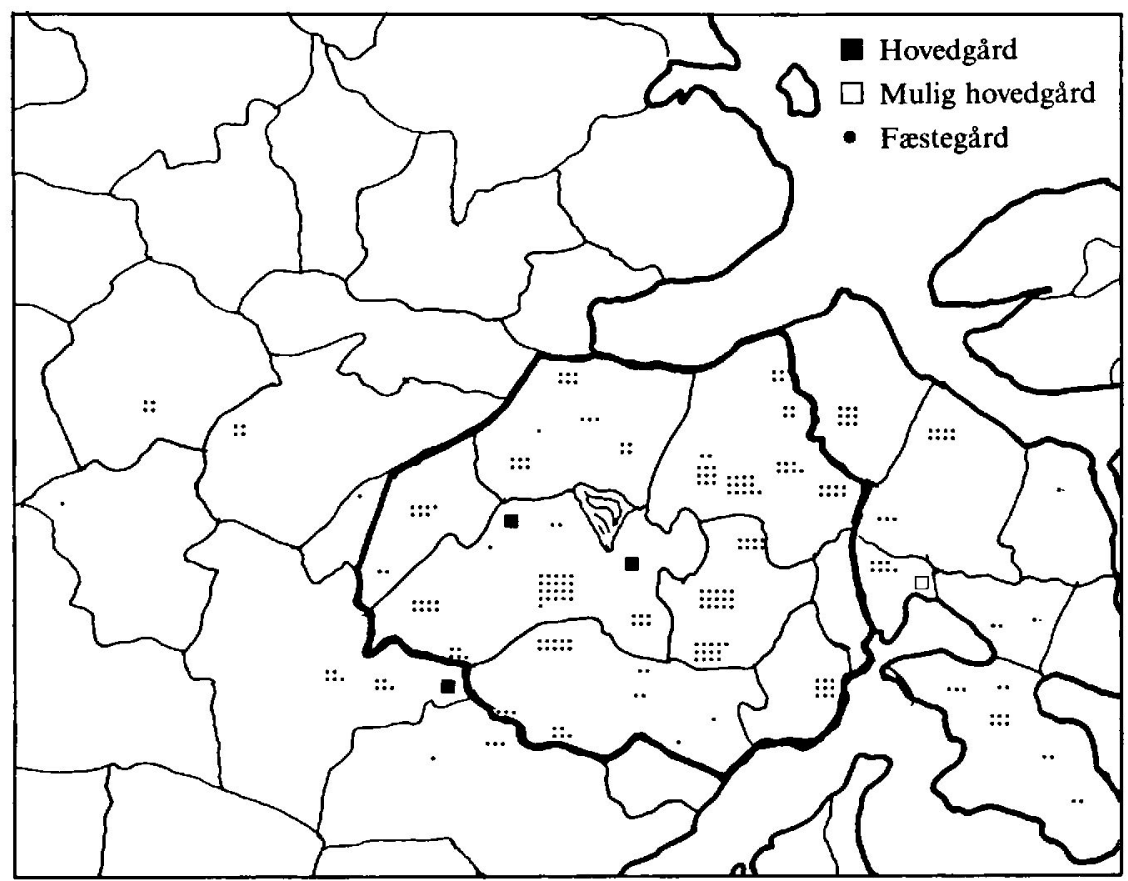

Kortet viser Sagdrd-godsets imponerende omfang og arrondering $i$ 1543. Tre fjerdedele af fastegårdene la $i$ Lundtoft herred (markeret med fed streg), og en god del af de ovrige lige ost eller sydvest for herredsgransen. Strogods var der meget lidt af. Godset bestod helt overvejende af fastegårde, men det omfattede ved midten af 1500-tallet ogsd mindst tre herregdrde: Søgård, Artoft og Stoltelund. Hertil kommer muligvis Holbak, hvis status pd dette tidspunkt er usikker. Kort: forfatteren.

Fldre, der dengang rådede over Lundtoft herred. Gregers Ahlefeldt fik to gårde $\mathrm{i}$ Bjerndrup, der var det eneste, han og broderen manglede $\mathrm{i}$ at eje hele Kliplev sogn. Til gengæld afstod han to gårde i Ravsted. ${ }^{22}$ Det var imidlertid eneste gang, det lykkedes at erhverve selvejergods i Lundtoft herred.

Mulighederne for godserhvervelser kom derfor stort set til at begrænse sig til handler med Hertug Hans den Yngre, der efterhånden satte sig endnu stærkere på Als og Sundeved, end Ahlefeldterne havde gjort på Lundtoft herred. Begge parter havde interesse $i$ at afrunde deres besiddelser $i$ forhold til hinanden. I 1580'erne overlod hertugen Ahlefeldterne to gårde i Bolderslev sogn og de fem gårde i Holbøl sogn, der tidligere havde hørt til Haderslev amt. ${ }^{23}$ Til gengæld afstod Daniel Rantzau, der var gift med ejerinden af det halve Søgård, i 1584 en gård i Dynt og én i Skodsbøl til hertugen. ${ }^{24}$ Et større mageskifte mellem hertugen og Ahlefeldterne fulgte i 1601 . Hertugen fik denne gang 2 gårde i Skelde, 2 i Stenderup, 2 i Dybbøl og 4 i Blans. Til gengæld afstod han 13 gårde i Adsbøl, Fiskbæk og Bojskov til Ahlefeldterne. ${ }^{25}$ Modsat kongen og 
de øvrige hertuger tog Hans den Yngre ikke hensyn til, at bønderne i disse byer var selvejere. Disse mageskifter blev i 1637 fulgt op af endnu ét, hvor Ahlefeldterne afstod en gård i Gammelgab og i stedet fik én i Avnbøl af Hans den Yngres søn, hertug Philip af Glücksborg. ${ }^{26}$

Ahlefeldterne ejede desuden i 1700-tallet 6 helgårde i byer, der slet ikke nævnes i fortegnelserne fra 1543: 2 i Foverup, Ravsted sogn, 2 gårde i Visgårde, Kliplev sogn og 2 i Terkelsbøl, Tinglev sogn. ${ }^{27}$ Regnes de for købt, var der i alt erhvervet 28 gårde og afstået 13 mellem 1543 og 1670. Det var kun en ringe forandring for så stort et gods. Først købet af Ballegård, der omfattede ca. 30 helgårde, betød en væsentlig udvidelse. ${ }^{28}$ Under alle omstændigheder var ændringerne i godsets omfang udadtil dog beskedne over så langt et spand af år. De virkelig væsentlige forandringer med godset skete indadtil.

\section{Flere og større hovedgårde}

Den mest afgørende ændring bestod $i$, at der blev flere hovedgårde, og at de fik langt større betydning. Søgård-Gråsten var på det punkt del i en mere almen udvikling, der primært fandt sted i Østeuropa i løbet af 1500- og 1600tallet. Godsejerne oprettede nye herregårde og udvidede dem, de havde i forvejen. Mange fæstegårde blev ofre for herregårdenes ekspansion. Det endte i Rusland, Polen og Østtyskland med, at godsejerne helt levede af indtægterne fra herregårdene. Bøndernes opgave blev at gøre hoveri. Tilløb til en sådan udvikling kan ses i Sønderjylland fra anden halvdel af 1500-tallet, hvor der opstod nye hovedgårde såvel $i$ de kongelige og hertugelige amter som på de adelige godser. I amterne tog hovedgårdsoprettelserne dog hurtigt af, mens de fortsatte på de private godser i Sydøstslesvig og på Søgård. ${ }^{29}$

1 middelalderen nævnes ikke andre hovedgårde under godset end Søgård selv, og så Holbæk, som nabogodsejeren blev fordrevet fra. Søgård var en meget stor gård i 1700-tallet, og det går formentlig tilbage til middelalderen, da der ikke kendes til nedlæggelser af bondegårde omkring den. Det første indtryk af gården får vi fra akterne fra en retssag, der i 1569 blev ført mellem Gregers Ahlefeldts enke Anna Ahlefeldt på den ene side og Frantz Ahlefeldts døtre Mette og Dorothea Ahlefeldt samt Dorotheas mand, Daniel Rantzau, på den anden. ${ }^{30}$ Både en primitiv skitse, der er bilagt akterne, og teksten viser, at de to parter havde hver sine stalde og lader. De havde også delt de egentlige kornmarker (de såkaldte kobler), men den ene part klagede over, at delingen ikke var lige. Græsningsrettigheder var derimod fælles. Det gjaldt også retten til at sætte svin på olden i skovene. Den ene part anførte, at modparten havde 
overtrådt en aftale om, at begges fogder skulle sætte brændemærke på svinene og derved kontrollere, at der var lige mange svin fra hver ejer.

Til Søgård hørte en lang række "særmarker«, der var spredt ud over flere sogne. Blandt dem var tre marker i Felsted sogn, nemlig Assenholm i vest, Bøghoved i nordøst og Grøngrøft i sydøst. Andre særmarker var Kværsdam i Kværs sogn, Dalsgård og Ulsnæs i Rinkenæs sogn og Fisknæs ved Gråsten for blot at nævne nogle af de vigtigste. Det synes især at have drejet sig om skove og græsgange. At dømme ud fra klager fra hertugelige bønder i Lundtoft herred var en række af disse arealer først gjort til særmarker i 1500-tallet. ${ }^{31}$ Mange af disse særmarker blev i øvrigt fortsat brugt af bønderne.

Procesakterne fra 1569 viser, at godset da omfattede et par avlsgårde ud over Søgård. Der citeres blandt andet en aftale fra 1541, hvorefter Frantz Ahlefeldt fik Årtoft i Kliplev sogn, Holbæk i Adsbøl sogn og Dalholt i Løjt sogn, mens Gregers Ahlefeldt alene fik Stoltelund i Tinglev sogn. Årtoft var ifølge sagsakterne fra 1569 allerede i Frantz Ahlefeldts tid et »Vorwerk«, en avlsgård, og der var en foged på gården. Når Stoltelund kunne modsvare en avlsgård og to andre gårde, må også den have været en avlsgård allerede ved midten af 1500-tallet. Det underbygges af, at der i procesakterne står, at Gregers Ahlefeldt uretmæssigt havde afgræsset jorder ved Øster Gejl med "sit« kvæg fra Stoltelund. I andre tilfælde nævnes udtrykkeligt, hvis det er én af parternes bønder, der har gjort noget forkert. Endelig er det værd at bemærke, at der i 1543 hverken blev svaret skat af Stoltelund eller Årtoft. Også det tyder på, at de var hovedgårde. Med stor sikkerhed var de det i 1580. Da nævnes Daniel Rantzau nemlig som ansvarlig for "Sehgarden, Stoltenlundt und Artoft « $\mathrm{i}$ en liste over hertugdømmernes godser og adel. ${ }^{32}$ Hvornår disse hovedgårde er oprettet vides ikke, men de omtales ikke før 1500.

I 1543 blev der heller ikke betalt skat af Holbak, men derimod nok af Dalholt. Det kunne betyde, at Holbæk også var hovedgård på daværende tidspunkt. Procesakterne fra 1569 kan tolkes i samme retning. Daniel Rantzau og hans parti klagede over, at Anna Ahlefeldt var kommet ved nattetide med fogder, karle og hvad folk, hun havde kunnet samle. De havde høstet syv store læs havre på Holbæks marker og ført høsten til Søgård. Klageren omtalte Holbæks marker som »sine « - ikke som sine bønders. Var Holbæk regnet for hovedgård midt i 1500-tallet, varede det dog ikke meget længere.

Til gengæld opstod der nye hovedgårde. Én af disse var Gråsten. Den skal ifølge gamle overleveringer have sin rod i et jagthus, og topografen Gude anfører, at den første Gregers Ahlefeldt, der døde i 1559, opførte en avlsgård i Troldsløkke syd for slotssøen. ${ }^{33}$ Procesakterne fra 1569 tyder nærmest i den modsatte retning. Påfaldende er det $\mathrm{i}$ hvert fald, at Gråsten slet ikke nævnes. Herregården synes derfor først oprettet senere. Gråsten nævnes første gang i 


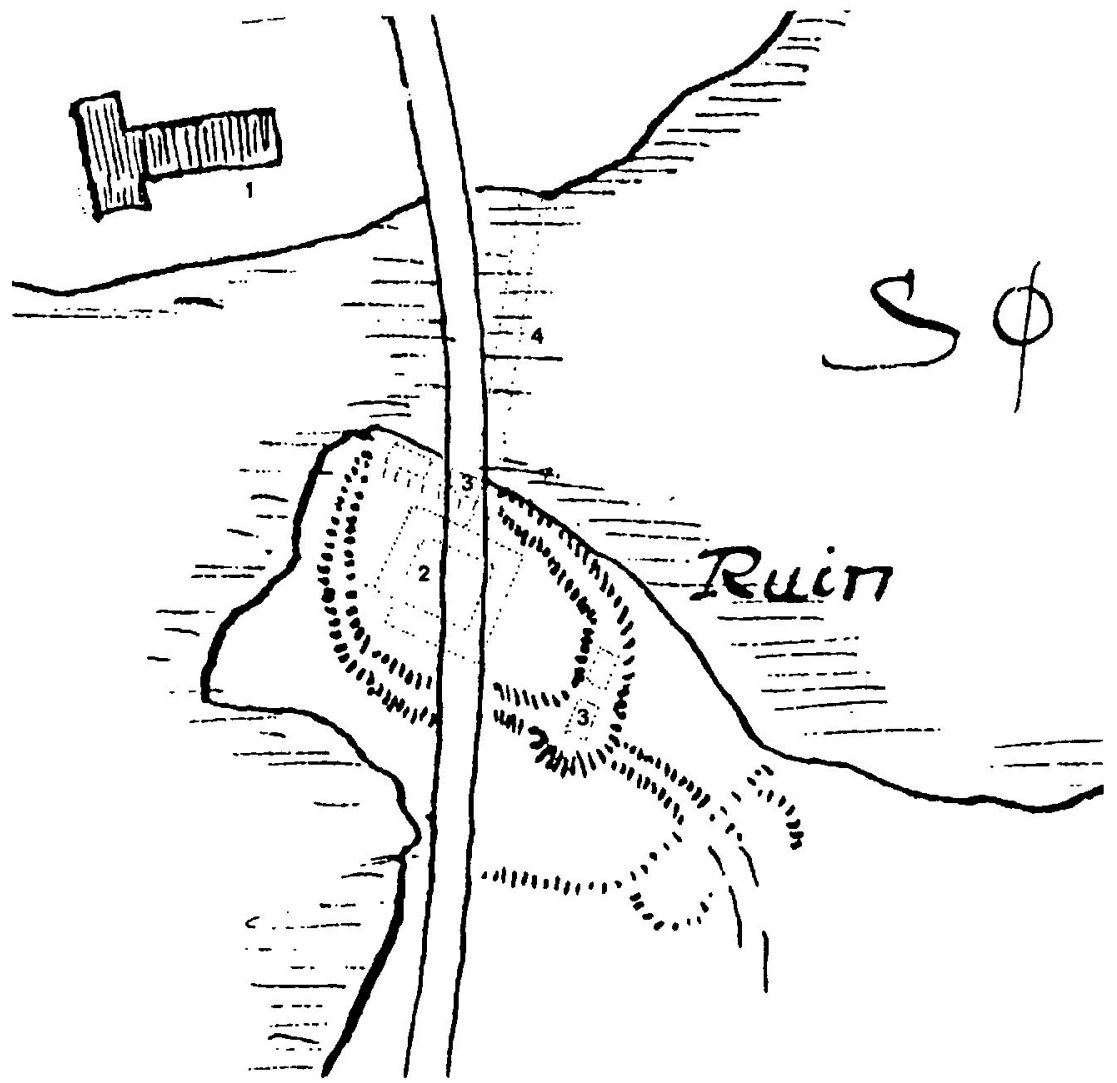

1: den nuværende hovedbygning, 2-4: mulig beliggenhed i 1500-tallet, 2: hovedbygning, 3: stalde, 4: »Lange bro«

Museumsinspektor J. Rahen lavede i 1921 en skitse af Sugdrds voldsted. Den findes nu pd Haderslev Museum og bringes her $i$ udsnit. Ringvolden har gennem drhundrederne udviklet sig til et lavt nas. Tvars hen over det er landevejen Aabenraa-Flenshorg fort i 1847.

Med udgangspunkt i tegningen fra 1569 har denne artikels forfutter skitseret, hordan borgen og staldene kunne have ligget: borgen midt i omrddet inden for voldene og staldene pa selve ringvoldens bredeste steder (prikket signatur). Skitsen er formentlig rigtig i princippet, men ikke i den konkrete udforelse. Den hidtil eneste udgravning fra 1920 var meget nodtorfig og fastslog ikke bygningernes pracise beliggenhed, men der blev dog fundet murrester inden for volden.

1600, hvor Gregers Ahlefeldt (II) kaldes herre til Søgård, Stoltelund og Gråsten. ${ }^{34}$ I november 1603 brændte Gråsten og blev erstattet af en ny og større herregård. Slottet var færdigt 1616 og blev hovedsæde for den ene gren af slægten til Søgård. ${ }^{35}$

Lidt længere mod nordvest opstod hovedgårdene Grøngrøft og Ladegård. 
De lå lige ved siden af hinanden og tilhørte hver sin af ejerfamiliens to grene. I 1569 omtales Grøngrøft som "særmark«. Marken var fælles, men Anna Ahlefeldt havde indhegnet en del af den, Kajsmaj. Samtidig havde begge parter ladet bygge hver sit »hus«, hvorunder en del af marken blev drevet. En egentlig herregård var der næppe tale om endnu. ${ }^{36}$

$\mathrm{Da}$ herregården blev oprettet, slugte den imidlertid ikke alene hele særmarken, men også en del af nabobyen Vårbjerg. ${ }^{37}$ I 1543 havde Frantz og Gregers Ahlefeldt hver fire bønder i denne by, der nævnes mellem Tørsbøl og Kværs. I en liste over Frantz Ahlefeldts bønder fra 1549 hedder byen nu »Nilagaard « nye ladegård. Det er blevet tolket sådan, at enten Grøngrøft eller nabohovedgården Ladegård havde taget byens plads. Under Nilagaard nævnes imidlertid de samme fire bønder, Frantz Ahlefeldt havde i Vårbjerg $1543 .{ }^{38}$ I 1569 omtales Nilagaard dels som en landsby, dels som en særmark, som tilhørte Anna og Mette Ahlefeldt. En herregård står der intet om. Forholdsvis kort derefter synes byen imidlertid at være forsvundet, og i 1599 nævnes Grøngrøft for første gang som herregård ${ }^{38 a}$. Det mest sandsynlige er således, at de to hovedgårde først er opstået $i$ slutningen af 1500-tallet.

Regner man med, at Vårbjerg eller »Nilagaard« måtte vige for herregårdsmarker før 1600, er det den ældste kendte nedlæggelse af bondegårde under Søgård. Ellers var de nye hovedgårde især vokset frem på mange særmarker, og det vil sige på jord, der ikke var under plov. Hovedgårdenes ekspansion kom imidlertid snart efter til på helt anden vis at berøre bondebyerne. Fem år efter, at Ahlefeldterne i 1601 havde fảet Hans den Yngres del af Adsbøl, Fiskbæk og Bojskov, indgik de to grene af familien et mageskifte, hvorved Hans Ahlefeldt til Gråsten fik Frederik Ahlefeldts andel af Fiskbæk samt gården Holbæk. Til gengæld fik Frederik Ahlefeldt Gråsten-grenens halvdel af byen Årup $\mathrm{i}$ Ensted sogn. Dette mageskifte må have været led $\mathrm{i}$ en nøje planlagt strategi for at skabe mulighed for at oprette hovedgårde. Det lod sig ellers vanskeligt gøre, når næsten alle landsbyer var delt mellem begge grene af slægten. Mange steder var der også selvejere, men det gjaldt netop ikke disse to landsbyer. Næppe var de samlet på én hånd, før de måtte vige for nye hovedgårde. Herrerne til Gråsten lagde i øvrigt også Adsbøl by under dels Fiskbæks og dels Gråstens hovedgårdsmarker. ${ }^{39}$

Antallet af hovedgårde var nu oppe på 8. Den ene gren rådede over det halve Søgård samt Stoltelund, Gråsten, Ladegård og Fiskbæk, den anden over det andet halve Søgård, Årtoft, Årup og Grøngrøft. I 1650'erne føjedes endnu to til listen, idet byerne Bojskov i Ullerup sogn og Kelstrup i Holbøl sogn nedlagdes og gjordes til ladegårde. ${ }^{40} \mathrm{Så} \mathrm{stilnede} \mathrm{nedlæggelserne} \mathrm{af} \mathrm{bondegårde}$ af, men så sent som 1718 nedlagdes den store landsby Kiding i Felsted sogn. Den talte på det tidspunkt 17 halvgårde. ${ }^{41}$ På reformationstiden omfattede 


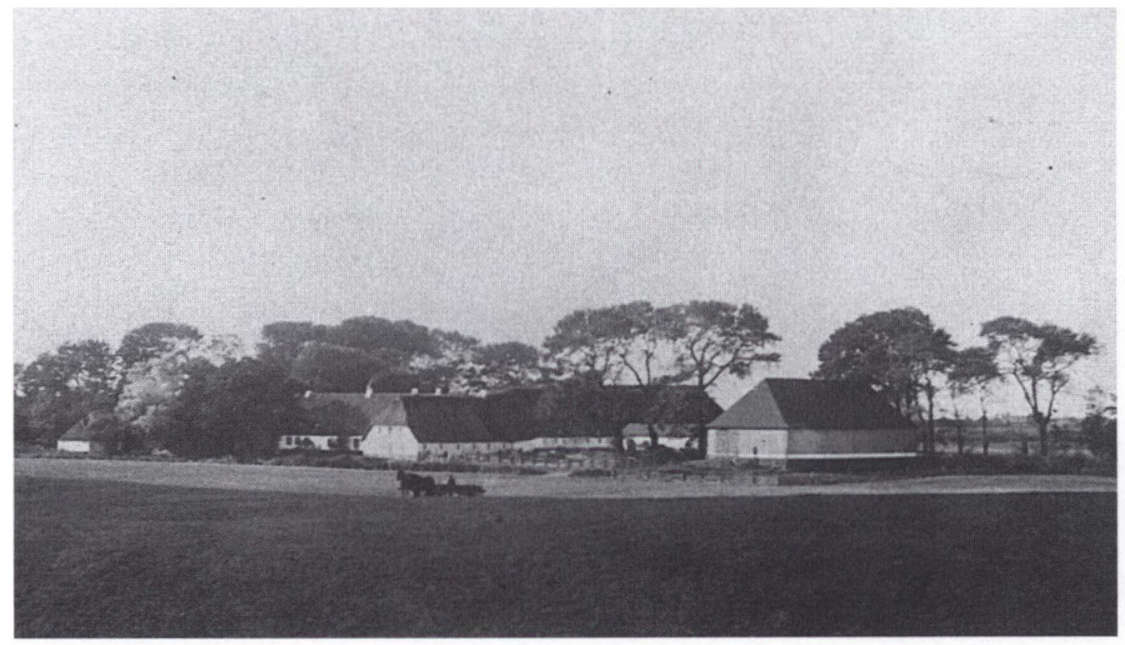

Ladegård i Kvars sogn var én af de mange nye hovedgårde, der efterhänden opstod inden for Sogårdgodskompleksets rammer. Disse avlsgärde havde $i$ Ahlefeldternes tid nok store stalde og lader, men beskedne hovedbygninger, da ejeren ikke boede der. Det blev ikke vasentligt anderledes efter auktionen 1725, selvom bl.a. Ladegård blev et selvstandigt gods. Derfor er Lundtoft herred fattigt på slotsagtige bygninger, selvom hovedgdrdene har ligget så tat $i$ omrâdet. Foto: Historiske Samlinger for Sonderjylland.

den 8 helgårde. Endelig er gården Fruermark forsvundet $\mathrm{i}$ sidste halvdel af 1600-tallet. ${ }^{42}$ Den må være lagt under Årtoft.

\section{Fæstegodsets forvandling}

Med disse oprettelser af hovedgårde havde godset skiftet karakter. Det gods, der i 1400-tallet næppe talte mere end én reel herregård, var blevet omskabt, så det til slut omfattede 13 hovedgårde, hvoraf kun 2 var købt, mens 10 må formodes oprettet mellem $1500 \mathrm{og} 1718$. Det havde kostet ganske mange fæstegårde. Nedlæggelsernes omfang og forløb kan nogenlunde sammenfattes som følger: 
Tabel 1. Bondegårde lagt under hovedgårde på Sogård-Gråsten

\begin{tabular}{|c|c|c|c|}
\hline Periode & Hovedgård & Nedlagte byer & Nedlagte gårde \\
\hline Før 1600 & $\begin{array}{l}\text { Ladegård } \\
\text { Grongrøft }\end{array}$ & Vårbjerg & 8 \\
\hline \multirow[t]{3}{*}{$1600-1650$} & Gråsten & Adsbøl & 4 \\
\hline & Fiskbak & Fiskbæk & 11 \\
\hline & Årup & Årup & 6 \\
\hline \multirow[t]{3}{*}{$1650-1700$} & Kelstrup & Kelstrup & 4 \\
\hline & Bojskov & Bojskov & 7,5 \\
\hline & Årtoft & Fruermark & 1 \\
\hline Efter 1700 & Kiding & Kiding & $8.5^{*}$ \\
\hline
\end{tabular}

* Kiding by talte rent faktisk 17 halvgårde i 1718, men de er her omregnet til helgårde for at få sammenlignelige tal.

Det skal ses i forhold til, at det oprindelige fastegods var på 251.5 plove (eller snarere omkring 240 , hvis man tager udgangspunkt i skatteansættelsen fra 1549). Heraf var der i mellemtiden afstået 13 gårde og til gengæld købt omkring 60. Af det antal helgårde, der havde været på reformationstiden, var altså næsten hver femte forsvundet. I kongeriget som helhed forsvandt noget over $5 \%$ af gårdene, i herregårdsdriftens danske hovedområder Lolland-Falster og Sjælland 7-10\%. ${ }^{43}$ Endda kan nedlæggelserne på Søgård-Gråsten have været endnu mere omfattende, for listen omfatter alene landsbyer, der forsvandt helt. Langt vanskeligere er det at afgøre, om enkelte gårde eller endda enkelte marker fra andre landsbyer også lagdes under hovedgårdene. En enkelt antydning af, at noget sådant skete, har vi fra retssagen i 1569. Her klagede Anna Ahlefeldt over, at jomfru Mette havde lagt noget af K.liplev bymark til Årtoft og sået det til med boghvede. Modparten benægtede dog blankt denne påstand og hævdede, at skellet stod, hvor det altid havde stået. I begyndelsen af 1700tallet blev et par gårde flyttet $\mathrm{i}$ forbindelse med en "nyordning" af Skovbølgårds marker. ${ }^{44}$ Det kan meget vel have indebåret inddragelse af jord under hovedgården. Det er meget tænkeligt, at der også i andre tilfælde blev taget jord fra landsbyer og lagt under hovedgårde.

Egentlige gårdnedlæggelser har der derimod næppe været mange af, ud over de omtalte landsbyer. Når man lægger halvgårde, trekvartgårde og andre brøker ifølge en godsoversigt fra 1709 sammen, så kommer man i de fleste tilfælde til det antal hele gårde, der var på stedet i 1543, korrigeret for kendte godshandler. Her og der var der faktisk en helgård for meget i 1709.45 Det kan betyde, at der var enkelte øde gårde i 1500-tallet, som ikke betalte skat. Et væsentligt fald $i$ antallet af helgårde kan kun konstateres i én gruppe af landsbyer: Kliplev, Vilsbæk, Lundtoft, Øster Gejl og Gejlå. De ligger alle omkring Hærvejen. I 1543 betalte bønderne i Vilsbæk og Kliplev ingen skat med ud- 
trykkelig henvisning til, at de havde været generet af kongens krigsfolk. ${ }^{46}$ Også i 1600-tallet blev egnen stærkt plaget af plyndrende soldater. Hans Ahlefeldt oplyste således i 1660 følgende: "Da mit gods Søgård ligger ved den store

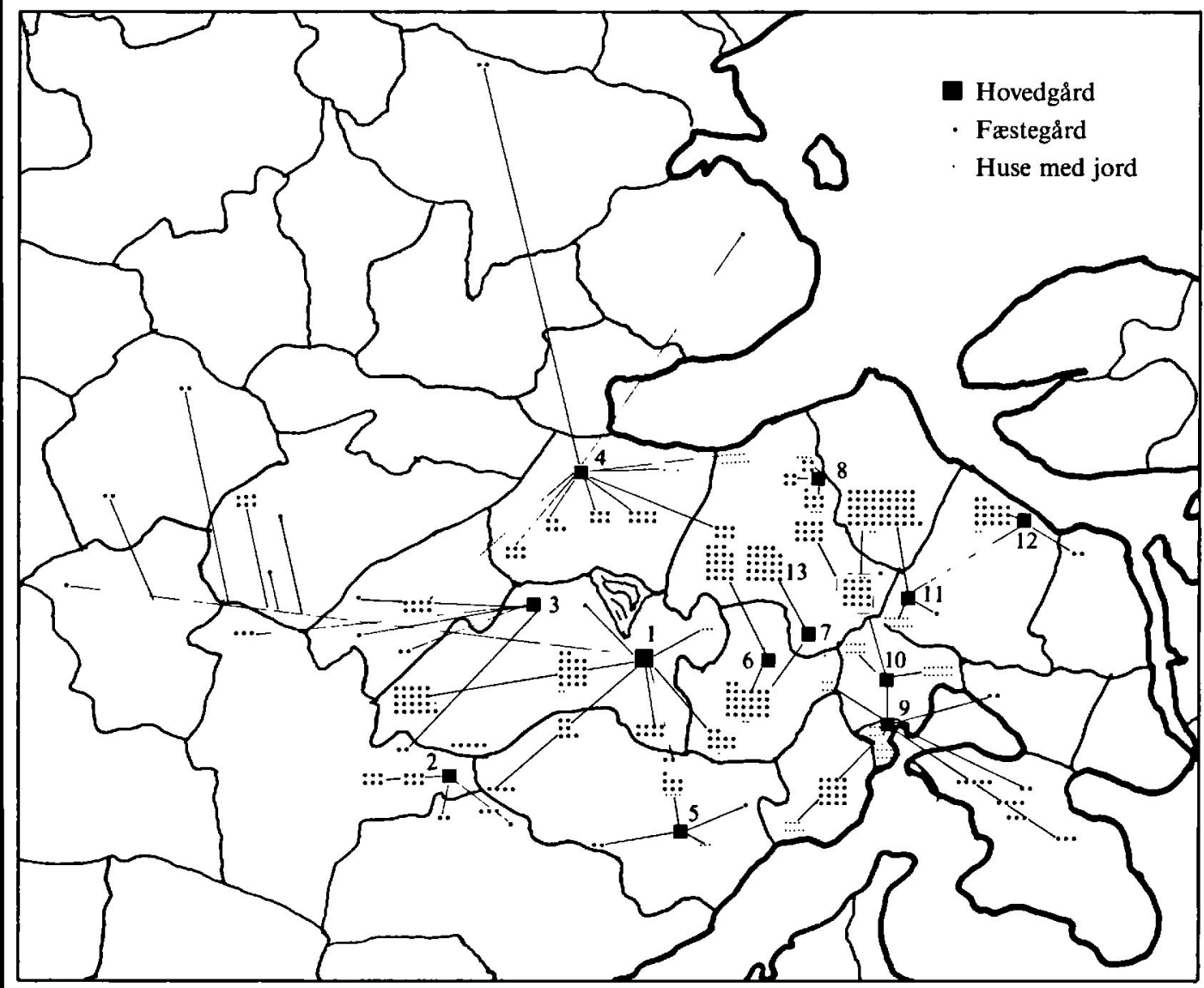

Hovedgårde: 1: Søgård, 2: Stoltelund, 3: Årtoft, 4: Årup, 5: Kelstrup, 6: Ladegård,

7: Grøngrøft, 8: Skovbølgård, 9: Gråsten, 10: Fiskbæk, 11: Bojskov,

12: Ballegård, (13: Kiding).

Sogård-Gråsten 1709.

Kortet viser godset på sit hojdepunkt. Det er nu tydeligt praget af de mange hovedgdrde pà dette tidspunkt 12 i alt. Tallet steg fa dr efter, da byen Kiding blev nedlagt til fordel for en ny hovedgård (stiplet signatur). Stregerne viser, hvilke landsbyer, der $i 1725$ blev lagt til hvilke hovedgårde. De to store byer Bovrup og Kvars var begge delt mellem to godser. Det fremgàr endvidere, at der pa Grastenegnen slet ikke var bondergårde tilbage, men kun herregdrde og huse med jord. 
hærvej, har det i krigstid lidt stor overlast. Bestandig har tropper passeret forbi på frem- og tilbagemarch og indkvarteret sig for natten. Særlig slem var ankomsten af vore allieredes hær. Da blev undersåtterne fordrevet og helt ruineret. Af de 56 plove, som godset står opført til i landets matrikel, er over 30 lagt øde og afbrændt, så jeg har af hele godset ikke fået den mindste afgift . $^{47}$

Hovedgårdsoprettelser og krigsfolkenes hærgen havde kostet op mod en fjerdedel af godsets bondegårde livet. Det blev ikke fuldt ud kompenseret ved de tilkøb af frestegods, der var sket. Alligevel steg gårdtallet fra 252 i 1543 til 392 i 1709. Det skyldes, at også de fæstegårde, der ikke blev nedlagt, blev udsat for en markant omstrukturering. De fleste af dem blev nemlig delt. Gårddelinger var udbredte i det østlige Sønderjylland i 1500-tallet. Enkelte steder fortsatte det i 1600-tallet. Et godt eksempel er Varnæs birk lige op ad Søgårdgodset. Her var der i 153530 ens gårde. Omfattende delinger øgede tallet til 45 gårde i 1609 og 54 i 1685.48

Udviklingen var næsten den samme på Søgård, selvom vi ikke kan følge forløbet. I 1709 omfattede godset i alt 82 helgårde, 15 trekvartgårde, 15 5/8gårde, 247 halvgårde, 23 kvartgårde og 10 andre gårde, der var mindre end en halvgård. Disse betegnelser afspejler reelle forskelle. I gennemsnit såede helgårdene hvert år knap 17 tønder land til med korn, halvgårdene 9 tønder land og kvartgårdene $4 .{ }^{49}$ Enkelte af halvgårdene synes at have været smågårde fra gammel tid. I skattelisten fra 1543 nævnes ganske vist kun én halvgård, men i listen over Frantz Ahlefeldts bønder 1549 blev 14 gårde regnet for halvgårde, selvom det var de samme bønder, der seks år før havde givet fuld skat. ${ }^{50}$ Det forklarer dog kun en meget lille del af de mange halvgårde i 1709. Resten må være opstået ved delinger. Delingerne fortsatte efter alt at dømme i hele perioden. I hvert fald skete der mellem 1709 og 1721 omkring 20 gårddelinger, mens omvendt 7 gårde blev lagt sammen med andre. ${ }^{51}$

Ikke nok med gårddelingerne. Godset omfattede i 1709 også 99 huse, der årligt drev over 2 tønder land med korn, og yderligere 15 huse med et kornareal på 1-2 tønder land. I hvert fald de 99 var i realiteten smågårde. De lå næsten alle i godsets centrale område.

Denne udvikling er overraskende, for udbredte gårddelinger og nyoprettelse af smågårde hører normalt hjemme i egne med frie bønder. ${ }^{52}$ Stærkt godsejerstyrede områder var derimod præget af et konstant antal, temmelig store fæstegårde, og et stærkt stigende antal jordløse husmænd. Hans den Yngre låste således gårdtallet fast eller lagde endda gårde sammen i sit område. ${ }^{53}$ Det er betegnende, at Ballegårds tilliggende i Blans og Bovrup kun omfattede helgårde i 1656-57. Efter Ahlefeldternes overtagelse blev mindst halvdelen af disse gårde imidlertid delt, idet der 1709 kun var 11 helgårde i Blans og 6 i Bovrup. ${ }^{54}$ 
Modsat andre godsejere foretrak Søgårds ejere at lade flere få jord at dyrke og blive selvstændige landbrugere.

Ahlefeldterne valgte næppe deres særlige løsning for undersåtternes skyld. Det spredte gods, der kun i ringe grad kunne gøre hoveri, blev ved med mest at bestå af helgårde. Det var omkring hovedgårdene, at halvgårde og store huse florerede. De blev alle pålagt store hoveribyrder. Ahlefeldterne foretrak at fordele hoveriet på flere skuldre end de fleste andre godsejere. Derved gjorde de deres undersåtter mere lige indbyrdes end så mange andre steder, hvor skellet mellem gårdmænd og husmænd var afgrundsdybt i 1700-tallet.

\section{Herregårde og fæstegods}

De mange nedlæggelser af bondegårde havde været med til at skabe en balance mellem herregårdsmarker og bondejord, der var ganske anderledes end $\mathrm{i}$ kongeriget. Fra 1709 findes en oversigt over alle godsets fæstebønder og husmænd med jord. For hver gård opregnes både kvægbesætninger og den årlige udsæd af forskellige kornsorter. ${ }^{55}$ Tilsvarende oplysninger findes for hovedgårdenes vedkommende i auktionskataloget fra 1725 .

Oplysningerne om udsæden kan bruges til at beregne, hvor store arealer hovedgårde $\mathrm{og}$ bondegårde hvert år såede til med korn. Man såede én tønde rug, én tønde byg, knap én tønde boghvede eller to tønder havre pr. tønde land. Når man vil omregne udsæden til kornareal, skal havren derfor divideres med to. Det er så meget mere rimeligt, som en tonde havre også kun havde ca. den halve vægt og værdi af en tønde rug.

Ud af dette kommer, at hovedgårdene $\mathrm{i}$ alt havde et årligt tilsået areal på ca. 2.360 tønder land, mens bondegårde og husmandsbrug tilsammen såede ca. 4.300 tønder land til med korn hvert år. ${ }^{56}$ Tallene skal formentlig korrigeres lidt. Bønderne var nok tilbøjelige til at opgive for lave tal over for godsadministrationen for ikke at risikere, at godset strammede skruen over for dem. Omvendt må vi formode, at hovedgårdenes marker og besætninger snarest blev overdrevet i 1725, da auktionskataloget var en reklametryksag, der skulle lokke kunder til. Men det er ikke sandsynligt, at opgivelserne lå meget langt fra sandheden, for i hovedtrækkene var de lette at kontrollere. Det er derfor en rimelig konklusion, at hovedgårdenes samlede kornareal var omkring halvt så stort som bondegårdenes.

Det tilbageværende bøndergods svarede til 224 helgårde, og det vil sige, at hovedgårdenes jordtilliggende modsvarede ca. 110 helgårde. Heraf var halvdelen kommet fra de omkring 50 nedlagte bøndergårde. Resten må være jord, der allerede havde været hovedgårdsmark $\mathrm{i}$ middelalderen, nyopdyrkede are- 
aler under bl.a. Grøngrøft og Gråsten, hvor skov- og græsningsarealer synes forvandlet til hovedgårdsmark, og endelig muligvis enkeltmarker, der var taget fra bønderne.

Forholdsvis vejede hovedgårdene lidt tungere i den østlige del af godset end i den vestlige. De otte østligste hovedgårde Gråsten, Fiskbæk, Kiding, Bojskov, Ballegård, Skovbølgård, Grøngrøft og Ladegård havde tilsammen et årligt tilsået areal på ca. 1580 tønder land, mens deres bønder og husmænd drev ca. 2560 tønder land med korn hvert år. Vestpå var det årlige kornareal ca. 780 tønder land på hovedgårdene og ca. 1740 tønder land under bondegårde og husmandsbrug. ${ }^{57}$ Det betød, at hovedgårdene sad på $38 \%$ af den dyrkede jord i den østlige del og $31 \%$ i den vestlige. Denne forskel skyldtes, at hovedgårdsoprettelserne i perioden efter 1600 havde varet meget stærkt koncentreret til egnen omkring Gråsten. Her, på godsdistriktets og noget af hele rigets bedste jord, lå nu 6 hovedgårde på rad, som det ses af kort 2. I deres nære omegn var der ikke flere bønder tilbage. Til gengæld var de fleste af de store husmandsbrug koncentreret her i en række særlige husmandsbyer: Bojskovskov, Adsbøl, Fiskebækskov, Alnor, Horsekobbel, Bækken og Ladegårdsskov.

Forskellen mellem godsets østlige og vestlige del er dog ikke voldsom. Med henholdsvis $31 \%$ og $38 \%$ herregårdsmark placerer begge dele af godset sig midt mellem det danske og det østeuropæiske godssystem. På private godser i kongeriget udgjorde hovedgårdsmarkerne i gennemsnit 12-14\% af den dyrkede jord. ${ }^{58}$ Omvendt var herregårdsmarkerne ligefrem større end bondegårdenes samlede tilliggende i Østeuropa, hvad allerede halvøen Svans i Sydslesvig er et eksempel på. ${ }^{59}$

Indirekte har vi herigennem et mål for hoveribyrden. En typisk bonde på en halvgård under Søgård-Gråsten drev selv omkring 9 tønder land med korn og skulle så oven i dette pløje, harve og høste ca. 5 tønder land på én af hovedgårdene. En kongerigsk bonde med en gård af samme størrelse slap med at klare et par tønder land på hovmarken, mens omvendt en bonde i Svans skulle drive 15 tønder land hovedgårdsmark for hver 10 tønder land af hans egen jord. Også husmændene på Gråstenegnen var spændt ret hårdt for, idet de skulle gøre hoveri 2-3 dage om ugen. Til gengæld betalte de kun meget små fæsteafgifter. ${ }^{60}$

\section{Hovedgårdenes drift}

Hovedgårdene var alle bortforpagtede $\mathrm{i}$ de sidste Ahlefeldters tid, og dette mønster fortsatte både på de godser, hertugen af Augustenborg købte, og på Søgård-Årtoft. Det medfører, at godsregnskaber og lignende kilder kun siger 
meget lidt om, hvordan gårdene egentlig blev drevet. Som hovedregel optræder de alene i godsregnskaber og jordebøger som en forpagtningsafgift. Auktionskataloget fra 1725 angiver imidlertid både udsæd og kvægbesætning for hver enkelt gård. Trods de forbehold man kan have over for denne kilde, er den et uvurderligt indblik $\mathrm{i}$, hvordan de enkelte gårde blev drevet.

Kataloget giver det klareste indtryk af de østlige hovedgårde, idet det her opregner de enkelte marker. De kaldes kobler, hvilket angiver, at de var omgivet af hegn hver for sig. Der var fra otte til tretten kobler pr. gård. Omkring halvdelen af koblerne var sået til med korn, mens den anden halvdel lå hen med græs til græsning og hø. Lidt uden for mønstret falder Ladegård, idet hele otte af tretten marker her var udlagt til græs.

Bortset fra Gråsten opgives arealet af de enkelte kobler ved de østlige hovedgårde. Det sker normalt i tønder rugsæd, men på Fiskbæk i tønder havresæd. Det svarer til henholdsvis henholdsvis 1 og $1 / 2$ tønder land. For de øvrige hovedgårdes vedkommende kender vi alene det tilsåede areal. Ud fra dette må vi så skønne om det totale (se figur 1).

Figur 1. Hovedgdrdenes agerareal 1725.

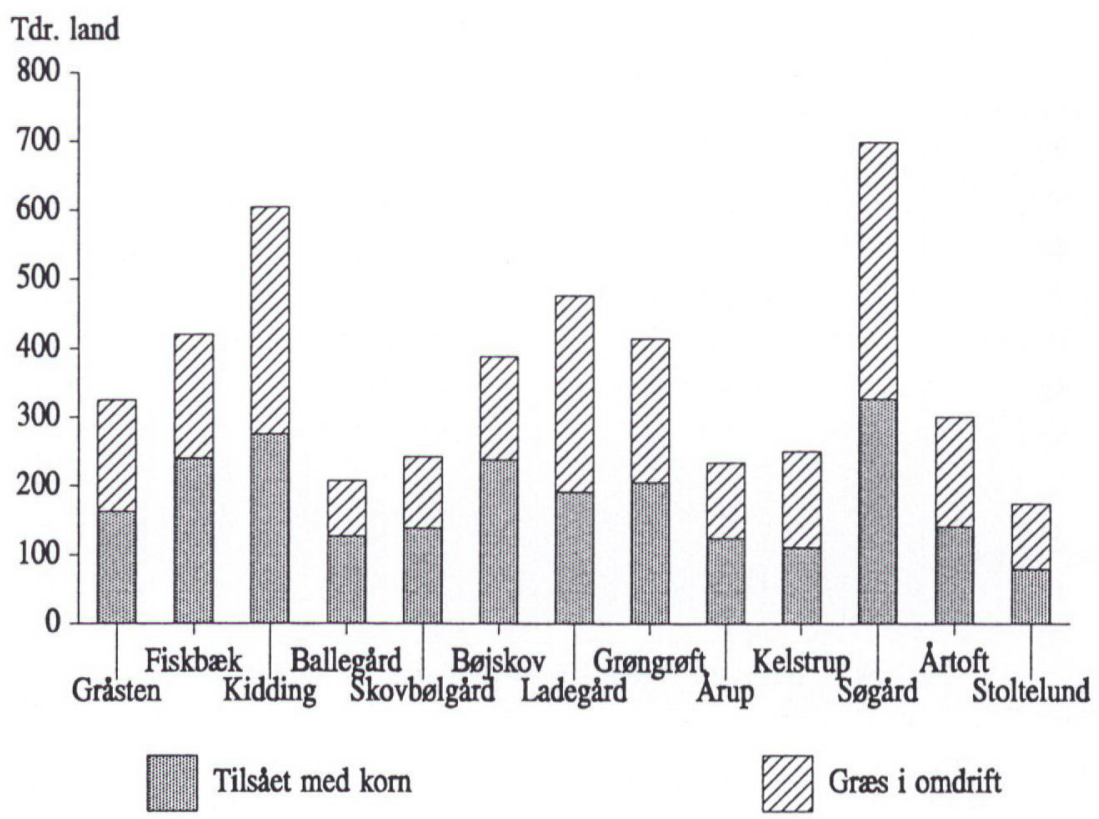

Kilde: LAA, Segård og Artoft godser nr. 2. 
Selvom vi ikke kender det samlede areal, kan der ikke være tvivl om, at det gamle hovedsæde Søgård var en kæmpegård. Kun fire af de elleve kobler skulle drives med korn. Nogle af de syv kobler, der lå hen med græs, var dog angiveligt mindre end de fire tilsåede, men under alle omstændigheder har en gård på halvringe jord næppe sået mere end højst halvdelen af arealet til hvert år. Det samlede areal har derfor snarest ligget omkring 700 tønder land.

Ellers er det påfaldende, at det er nogle af de mere anonyme og sent oprettede avlsgårde, der er de største. Når vi ser bort fra Søgård, var de fire andre gamle herregårde, Skovbølgård, Ballegård, Stoltelund og Årtoft, forholdsvis beskedne med markarealer på 150-300 tønder land. Det svarer nogenlunde til hovedgårdenes typiske størrelse $\mathrm{i}$ kongeriget. Blandt de senere oprettede avlsgårde var kun Kelstrup og Årup så beskedne, mens Grøngrøft, Ladegård, Bojskov og Fiskbæk og formentlig også Gråsten var store gårde på omkring 400 tønder land. Den sidst oprettede, Kiding, var endnu større. Det viser, at disse gårde var skabt med direkte henblik på at drive storlandbrug. De var virkelig store efter tidens norm. Søgård og Kiding svarer i agerareal til henholdsvis den næststørste og den tredjestørste herregård i Nørrejylland (Gam-

Figur 2. Hovedgårdenes kornareal 1725, fordelt på kornsorter.

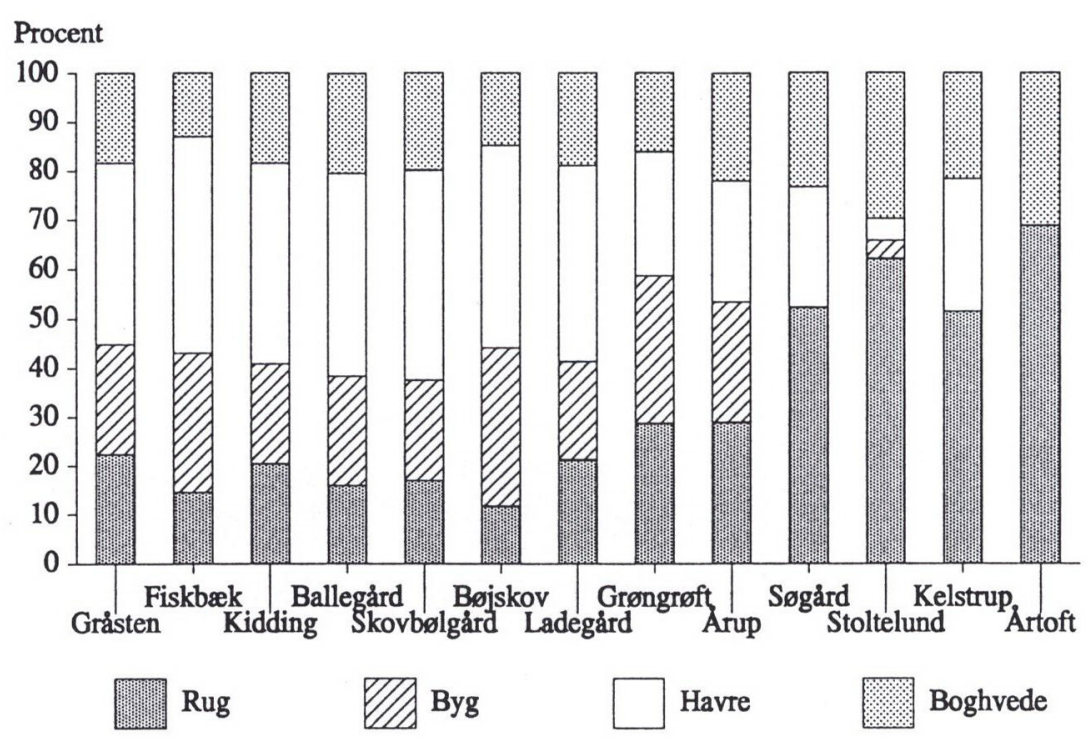

Kilde: LAA, Søgård og Artoft godser nr. 2. 
mel Estrup og Bygholm), og hvor der på de gråstenske godser alene var 5 hovedgårde med mere end 400 tønder land ager, var der kun 14 gårde af den størrelse i hele Nørrejylland. ${ }^{61}$ Store hovedgårde var imidlertid ikke så usædvanlige i Slesvig og Holsten. Således var en række af hovedgårdene på Sydals af samme størrelse som de gråstenske. ${ }^{62}$

Sædskiftet på hovedgårdene angives ikke direkte, men det fulgte i Sønderjylland normalt det princip, at en række år med korn blev efterfulgt af en årrække med permanent græs. Det gav den bedste græsning, og på den måde var såvel det midt- og vestjyske græsmarksbrug som det holstenske kobbelbrug indrettet. Auktionskataloget giver indtryk af, at det også gjaldt godserne under Gråsten, og alt andet ville også være særdeles overraskende.

På alle 13 godser under ét optog rug og havre hver omkring $30 \%$ af det besåede areal, mens byg og boghvede hver fyldte knap $20 \%$. Der var imidlertid store forskelle, som fremgår af figur 2. På de østlige godser, Gråsten, Fiskbæk, Kiding, Ballegård, Skovbølgård, Bojskov, Ladegård og Grøngrøft, var havren vigtigste kornsort. Den optog gennemgående ca. $40 \%$ af kornarealet, mens de øvrige kornsorter hver fyldte omkring $20 \%$ - byggen generelt lidt mere og boghveden lidt mindre. Denne fordeling af kornsorterne er typisk for Sønderjyllands mere frugtbare egne.

Den ekstreme modsætning er sandjordsgårdene Årtoft og Stoltelund. De lå ude $\mathrm{i}$ rugens land. Rug udgjorde to tredjedele af udsæden, og boghvede var den eneste anden kornsort af betydning. Også dette er typisk for egnen. På de magre midtsønderjyske jorder var rug og boghvede de eneste afgrøder, der gav et rimeligt udbytte.

Søgård, Årup og Kelstrup lå alle tæt ved selve israndslinien, og de indtog en mellemposition mellem lerjords- og sandjordsgårdene. Søgård og Kelstrup lignede mest sandjordsgårdene, idet der var rug i godt halvdelen af det tilsåede areal, mens resten var delt nogenlunde ligeligt mellem havre og boghvede. Byg forekom ikke. Årup lignede derimod mest de gode gårde østpå, blot betød havren mindre, idet der var en næsten ligelig fordeling mellem de fire kornsorter.

Auktionskataloget regnede med, at man på de gode gårde kunne sælge fem gange udsæden af rug og byg og fire gange udsæden af havre og boghvede. Tager man højde for, at næste års udsæd først skal trækkes fra den samlede høst, vil det reelt sige, at man regnede med henholdsvis seks og fem fold. Ude på sandet blev rughøsten sat én fold lavere. Men under alle omstændigheder ligger disse høsttal meget højt i forhold til, hvad man ellers kender fra datiden. De er formentlig overdrevne. Auktionskatalogets formål var som næunt at lokke købere til og skaffe så god en pris for godserne som muligt, og netop høsttallene var langt vanskeligere at kontrollere end tal for markernes størrelse. 

Tabel 2. Kvaghesatninger på hovedgårdene $i$ begyndelsen af 1700-tallet

\begin{tabular}{lrrrr}
\hline Antal køer & 1715 & $1725 \mathrm{a}$ & $1725 \mathrm{~b}$ & 0.1740 \\
\hline Gråsten & 100 & 120 & 170 & 160 \\
Fiskbæk & 120 & 120 & 126 & 120 \\
Kiding & & 160 & 180 & 180 \\
Ballegård & 50 & 40 & 54 & \\
Skovbølgård & 80 & 84 & 84 & \\
Bøjskov & 100 & 48 & 120 & \\
Ladegård & 130 & 130 & 144 & \\
Grøngrøft & 100 & 100 & 115 & 157 \\
Søgård & 160 & 160 & 162 & 32 \\
Stoltelund & 30 & 30 & 30 & 50 \\
Årtoft & & & & 100 \\
Keistrup & 50 & 50 & 50 & \\
Årup & 100 & 100 & 100 & \\
\hline I alt & 1020 & 1142 & 1367 & \\
\hline
\end{tabular}

Anm: 1725a er de køer, forpagteren havde overtaget fra godset, 1725b den totale kvægbesætning.

De forskellige kilder passer pænt sammen. Forskellen mellem tallene fra 1715 og de besætninger, forpagterne havde overtaget, beror væsentligst på, at $\mathrm{Ki}$ ding var oprettet i mellemtiden.

Der var malkekvægsbesæatninger på alle godsets hovedgårde. Ni af hovedgårdene havde store kvægbesætninger på 84-180 køer, mens kvægholdet på de sidste fire gårde var mere beskedent. Det falder straks i øjnene, at gårdene på den gode jord alle havde betydelige kvægbesætninger bortset fra Ballegård. Omvendt var kvægbesætningerne små på de tre mest udprægede sandjordsgårde. Årtoft havde endda slet intet egentligt hollænderi. Bortset fra dette skel mellem øst og vest svarer kvægbesætningerne nogenlunde til gårdenes størrelse, idet Gråsten avlsgård dog havde en meget stor kvægbesætning, men forholdsvis mindre kornmarker.

Hvor hovedgårdene holdt 1367 køer i 1725 , var der 16 år tidligere 2384 på fæstegårde og husmandsbrug. ${ }^{65}$ Det betød, at hovedgårdene havde ca. $36 \%$ af køerne eller samme andel, som de havde af kornmarkerne. Derimod holdt hovedgårdene generelt kun 15-20 heste. Det svarer til 3-4 bondegårdes hestehold, hvorimod kvægholdet på hovedgårdene snarere svarede til 20-40 bondegårdes besætning. Forklaringen er, at herregårdsmarkerne blev drevet med hovbøndernes heste.

Malkekvæg var det eneste husdyrhold af betydning. Kataloget anfører dog, at der på nogle af ladegårdene blev holdt et mindre antal stude. På Årtoft var der et ret betydeligt schäferi - dvs. en fårestation. Omkring 1750 havde den $\mathrm{i}$ alt 600 får. ${ }^{66}$ Mærkeligt nok opgøres indtægterne fra schäferiet ikke i kataloget. 


\section{Indtægterne}

Med så mange hovedgårde som de gråstenske godser omfattede, må man vente, at de stod for den væsentligste del af godsindtægterne. Det var også tilfældet, hvilket fremgår af tabel $3 .^{67}$

Tabel 3. Godsernes indtagter omkring 1725

\begin{tabular}{lrrrrrr}
\hline Rigsdaler & 1721 & 1725 & 1742 & 1745 & 1726 & 1745 \\
\hline Gråsten & 1500 & 1810 & 1570 & 1600 & & \\
Fiskbak & 1450 & 1896 & 1060 & 1060 & & \\
Kiding & 2000 & 2499 & 1740 & 1646 & & \\
Årup & 800 & 1261 & 877 & 960 & & \\
Kelstrup & 600 & 796 & 550 & 550 & & \\
Søgård & 1600 & 2467 & & & 1600 & 1150 \\
Årtoft & 500 & 935 & & & 500 & 350 \\
Ballegård & 800 & 917 & & & & \\
Skovbølgd & 800 & 1160 & & & & \\
Bøjskov & 1100 & 2039 & & & & \\
Ladegård & 1300 & 1777 & & & & \\
Grøngrøft & 1035 & 1528 & & & & \\
Stoltelund & 510 & 542 & & & & \\
Fæstegods & 5272 & 5280 & 2035 & 2080 & 1743 & 1772 \\
Møller & 643 & 640 & 413 & 413 & & 341 \\
Andet & 550 & 590 & 1166 & 1239 & 344 & 411 \\
\hline I alt & 20460 & 26137 & 9411 & 9548 & 4435 & 4024 \\
\hline & & & & & & \\
\% & & & & & & \\
herregårde & 68 & 75 & 62 & 61 & 47 & 37 \\
fæstegods & 26 & 20 & 22 & 22 & 39 & 44 \\
møller & 3 & 2 & 4 & 4 & 6 & 8 \\
andet & 3 & 2 & 12 & 13 & 8 & 10 \\
\hline Anmarkng & & & & & & \\
\hline
\end{tabular}

Anmærkning: De fire sidste spalter omfatter kun dele af det oprindelige gods, hvilket er den vasentligste forklaring på, at indtægtsbeløbene fra fæstegods og møller er lavere end ifølge opgivelserne fra 1721 og 1725 .

De ca. 20.000 rigsdaler, auktionskataloget anslog hovedgårdenes udbytte til, savnede ganske vist bund i virkeligheden. I 1721 gav hovedgårdene i alt knap 14.000 rigsdaler, og Søgård-regnskabet fra 1726 antyder, at dette niveau var realistisk. Det var imidlertid ikke mindre end to tredjedele af alle indtægter. Regnskaber fra de 7 af de 13 godser viser dog, at indtægterne fra hovedgårdene faldt frem til 1740'erne, formentlig på grund af landbrugskrise og sygdomme.

De seks hovedgårde ved Gråsten var sammen med Søgård de mest indbringende med forpagtningsafgifter på mellem 1.000 og 2.000 rigsdaler. Det hænger naturligt sammen med, at de var de største. Man bemærker dog, at Kiding 
i kraft af sin gode jord gav større indtægter end Søgård, der havde mere jord. Tilsvarende gav forpagterne på de små østlige herregårde Ballegård og Skovbølgård hver 800 rigsdaler, mens de tre sandjordsgårde Årtoft, Stoltelund og Kelstrup kun gav 5-600 rigsdaler hver, og derfor ikke var de store aktiver for godsejeren.

De fleste af de øvrige indtægter er ens i de forskellige kilder. Fæstegodset gav noget over 5.000 rigsdaler eller omkring en fjerdedel af indtægterne. Møllerne bidrog med ca. 640 rigsdaler - $3 \%$ af alle indtægter. Langt det meste af dette beløb kom fra de tre store møller, Felsbæk Mølle, Munkemølle og Bjerndrup Mølle, der gav en årlig afgift på henholdsvis 150, 200 og 202 rigsdaler.

Alle andre indtægter betød meget lidt ifølge såvel jordebogen fra 1721 som kataloget. Regnskaber fra tiden efter 1725 viser imidlertid, at disse indtægter faktisk skæppede noget mere i kassen. For Søgård-Årtofts vedkommende betød salg af tørv, bøder og frikøb fra livegenskabet en del. For de gråstenske godser var det især teglværkerne, der i 1740'erne gav godsejeren en indtægt på

Figur 3. Godsernes indtagter 1721.

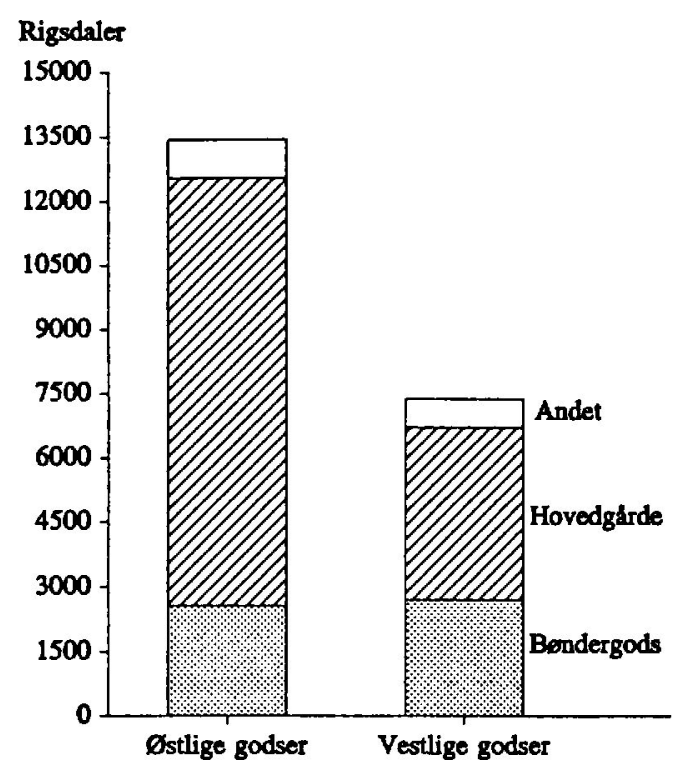

Kilde: LAA, grastenske godser nr. 153. 


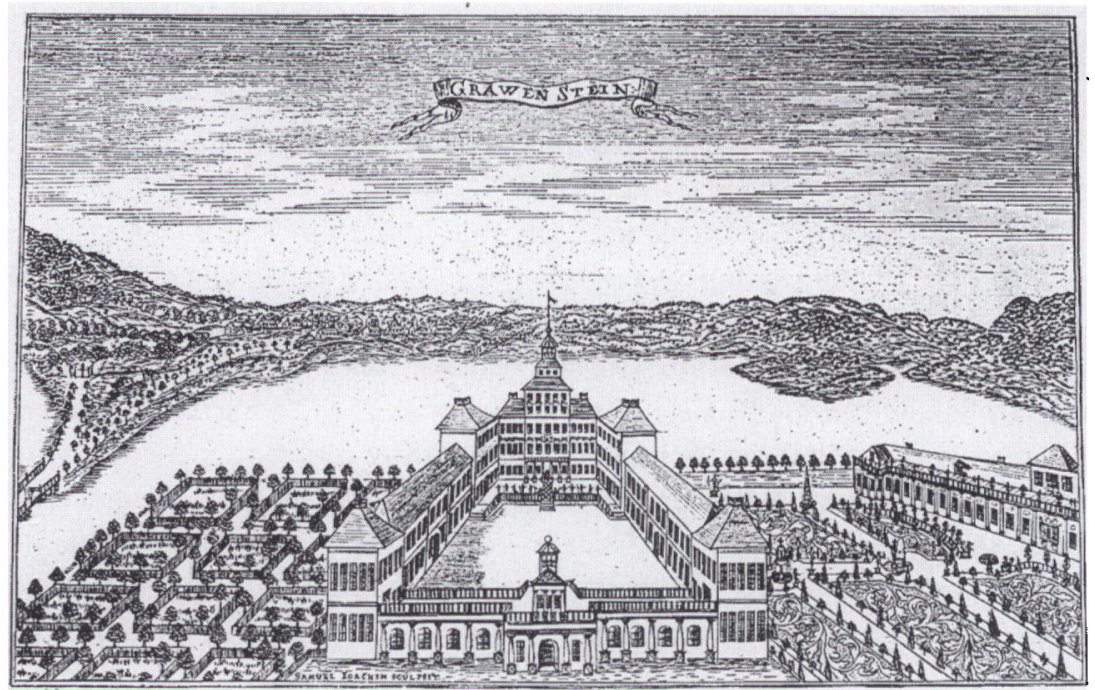

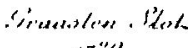

$$
\begin{aligned}
& \text { : in }
\end{aligned}
$$

Gråsten opstod $i$ slutningen af 1500-lallet som en beskeden herregård. Efter en brand $i$ 1603 $f_{\mathrm{y}}$ ttedes den til slottets nuvarende plads, og en ny hovedbygning stod fardig 1616. Den blev under storkansleren hovedsade for hele godset. Storkansleren og hans son opforte et slot, der med rette regnedes for den pragtigste privatbolig $i$ det danske rige. Alene orangeriet (drivhuset) til hojre i billedet skal have kostet den utrolige sum af 40.000 rigsdaler. Det er mere end Sogärd og Artoft kostede ved auktionen 1725! Bemark ogsd den store park i tidens franske stil. Ved den ahlofeldtske konkurs i 1725 lykkedes det at salge Grösten til den eneste, der var interesseret $i$ så stort et sonderjysk slot: hertugen af Augustenhorg. Slottets pragtige midtfloj brandte desvarre i 1757 og blev senere erstattet af den mere beskedne midtbygning. der nu kendes. Stik fra 1720 i Pontoppidans Theatrum Dania. 
omkring 700 rigsdaler om året. Alt i alt tegnede disse forskellige kilder sig ifølge regnskaberne for 7-10\% af indtægterne.

Der var imidlertid en regional forskel inden for godskomplekset, hvilket ses af figur 3. Afgifterne af bønderne og indtægter fra møller, kroer og udlejet jord beløb sig til nogenlunde det samme fra de to halvdele af godset. Den afgørende forskel var hovedgårdene. Mens de 8 østlige hovedgårde indbragte næsten 10.000 rigsdaler, var afgiften af de 5 vestlige hovedgårde kun godt 4000 rigsdaler $i$ alt. Det betød, at hovedgårdene tegnede sig for godt halvdelen af alle indtægter $\mathrm{i}$ vest, men tre fjerdedele $\mathrm{i} ø s t$. I øst havde man oprettet mange herregårde og dermed stillet store krav om hoveri, og til gengæld var især de mange husmænd med jord sluppet med ganske små fæsteafgifter. Vestpå var hoveribyrden noget mindre, og fæsteafgifterne til gengæld noget højere i forhold til gårdenes areal.

Det var de østlige godser, der stod for størstedelen af godsets indtægter. Jordebogen bestyrker tilliden til den sidste Ahlefeldts påstand om, at han havde bragt indtægten op fra 13-15.000 rigsdaler om året til nu 20.000 rigsdaler. ${ }^{68}$ I akterne vedrørende den ahlefeldtske konkurs sættes indtægterne til 21.000 rigsdaler, nogenlunde det samme som jordebogen viser. ${ }^{69}$ Det er virkelig meget. Tyve år senere, hvor landbrugspriserne var næsten de samme, ansås en af kongerigets største jordbesiddere, lensgreve Scheels, jyske godser på ialt omkring 5.000 tønder hartkorn kun for at give ca. 15.000 rigsdaler. ${ }^{70}$ Grevskabet Langeland på ca. 2.700 tønder hartkorn gav ifølge en opgivelse fra 1708 kun 4.500 rigsdaler om året. Et regnskab fra 1710-11 sætter dog bruttoindtægten til ca. det dobbelte. ${ }^{71}$ Med omkring 300 fæstegårde var grevskabet Langeland af næsten samme størrelse som de gråstenske godser. Søgård-Gråsten gav faktisk lige så store indtægter som 2-3 grevskaber. Det kan kun forklares ved, at den voldsomme satsning på hovedgårdsdrift og her ikke mindst på mejeribruget $\mathrm{i}$ høj grad betalte sig for godsejeren.

\section{NOTER}

1. Mikael Venge: Slægten Ahlefeldt og Søgård, SJY Årb 1987, s. 5-34; Poul Andersen: Graasten et slot og et sogn, Graasten 1986.

2. Henrik Fangel: Det middelalderlige Ejsbøl og den holstenske adels indvandring i hertugdømmet Slesvig, SJy Årb 1969, s. 104-30.

3. Esben Albrectsen: Den holstenske adels indvandring i Sonderjylland i det 13.-14. århundrede, Historisk Tidsskrift bd. 74, s. 81-152.

4. Louis Bobé: Slægten Ahlefeldts Historie Bd. 1-6, Kbh. 1897-1912, her bd. 1, s. 44 og 56; Albrectsen, anf. arb. s. 145f; Diplomatarium Danicum, 3. rk. 5 nr. $35-36$ (1357) og 3. rk. 9 nr. 536 (1375).

5. Bobé: anf. arb. bd. 1, s. 44f, 54 fog 60 fog bd. 3, bilag IV.1.

6. Diplomatarium Danicum, 3. rk. nr. V. nr. 35-36; jvf. Esben Albrectsen, anf. arb. s. 146. 
7. Bobé, anf, arb. bd. 1, s. 44ff, 56f, $62 \mathrm{f}$ og 70f, bd. 3. s. 123.

8. Bobé, anf. arb. bd. IV. s. 67 , samt bilag 2.1 .

9. Bobé, anf. arb. bd. 3, bilag IV.1.

10. Svend Aakjar (udg.): Kong Valdemars Jordebog, Kbh. 1926-45, bd. I, s. 9.

11. A. D. Jørgensen: Graastens ældre Historie, SJy Arrb 1889, s. 1-43.

12. F. Falkenstjerne og Anna Hude: Sønderjydske Skatte- og Jordebøger fra Reformationstiden, Kbh. 1895-99, s. 18, 46, 289-91 og 424-29.

13. Erik Ulsig: Danske Adelsgodser i middelalderen, Kbh. 1968, s. 50 og 230-35.

14. Delingen af fæstegårdene fremgår af skattelisten fra 1543, hvor de to brødres bønder anføres hver for sig. Delingen af hovedgård og enemærker 1535 fremgår af akterne fra en retssag i 1569 , LAS, Abt. 15, nr. 713.

15. Jens Viliam Jensen: Skifteprincipper og skiftepraksis for adeligt jordeogds i det 16. århundrede, i: Aage Andersen, Per Ingesmann og Erik Ulsig (red.): Festskrift til Troels Dahlerup, Århus 1985, s. 333-50. Afhandlingen viser, at man i kongeriget delte efter helt samme principper som på Sogård i denne periode.

16. LAS, Abt. 15 nr. 713.

17. Bobé, anf.arb. bd. $5 \mathrm{~s}, 101-5$.

18. RA, Glücksborg, pergament, b.3. Dokumentet opregner alene de fire herregårde, men specificerer ikke fæstegodset.

19. Bobé, anf. arb. bd. 3, s. 125f, 128, 130 og $132 f$.

20. Bobé, anf.arb., bd. 6 s. 7-64.

21. Erik Ulsig: anf.arb. s. $306 f$.

22. Emilie Andersen (udg.): De Hansborgske Registranter Bd. 2, Kbh. 1949, s. $462 f$.

23. Hans den Yngre fik Haderslev amts strøgods og heriblandt disse gårde som en del af arven efter Hans den Ældre i 1582, men da han i 1584 igen afstod strøgodset til kongen, manglede netop de 7 gårde. (RA, Hans den Yngres arkiv, pergament, A.a.5-6). De lå sidenhen under Søgård.

24. Det fremgår af et regnskab over Hans den Yngres bønder fra ca. 1602 på Deutsch Nienhof (RA, film D.69).

25. I regnskabet fra 1602 opregnes de ti bønder, Ahlefeldterne havde afstået (RA, film D.69). Til gengæld mangler regnskabet de bønder i Adsbøl, Fiskbæk og Bojskov, der før havde hørt under Sønderborg len (se Falkenstjerne og Hude s. 166-68). Gude anfører desuden, at hertugen i 1601 afstod disse bønder til Ahlefeldterne (Gude: Bericht von der Halbinsul Sundewitt, Altona 1778, s. 80).

26. Rigsarkivet, Glücksborg, pergament nr. B2, brev af 16/10 1637 .

27. LAÅ, Søgård og Årtoft godser, nr. 5, Generaluntersuchungsprotokol 1709.

28. Ballegårds tilliggende fremgår af en jordebog over hertugdømmet Nordborg fra 1656, RA, film D.69. Her anføres 35 gårde. Heraf blev 4 gårde afstået 1661 før salget til Ahlefeldterne (jvf. Trap bd. $26 \mathrm{s.}$ 1194).

29. Jens Jessen: Die Entstehung ung Entwicklung der Gutswirtschaft in Schleswig-Holstein bis zu dem Beginn der Agrarreformen, ZSHG, 1922, s. 1-206.

30. LAS, Abt. 15, nr. 713; jvf. Johan Hvidtfeldt i Danske slotte og herregårde, 2. udg. v. Aage Roussell, bd. 16, Kbh. 1967, s. 125ff.

31. Troels Fink: Udskiftningen i Sønderjylland indtil 1770, Kbh. 1941, s. 28.

32. Bobé, anf. arb. bd. 2, bilagsdelen s. 45 .

33. Gude, anf. arb. s. $82 \mathrm{f}$.

34. A.D. Jørgensen, anf. arb., s. $10 f$.

35. Gude, anf. arb. s. $82 f$.

36. Samme opfattelse har Johan Hvidtfeldt, se Trap: Danmark, bd. 26, s. 995.

37. Begge gårde havde i 1725 en mark, der hed Vårbjerg. Det fremgår af kataloget fra auktionen over de gråstenske godser 1725, LAÅ, Søgård og Årtoft godser, nr. 2.

38. RA, Slesvigske og holstenske regnskaber før 1580, Plov- og frøkenskat af adelen 1543-44. Heri findes også listen fra 1549.

38a. LAS, Abt. 7, nr. 6272. 
39. Trap, bd. 26., s. 932 og $955 f$,

40. Kelstrup: Trap bd. 26, s. 1010. Bojskov: Trap bd. 26, s. 1194 (v. Johan Hvidtfelt). Peter Kr. Iversen placerer sammesteds. s. 1190 nedlæggelsen af Bojskov tidligere.

41. Trap, bd. 26, s. 942.

42. Gården forekommer endnu på Johannes Meyers kort over Aabenraa amt fra 1648, men ikke i godsbeskrivelsen fra 1709.

43. Gunnar Olsen, Hovedgård og bondegård. Studier over stordriftens udvikling i Danmark i tiden 1525-1774, Kbh. 1957, s. 172. Gunnar Olsen når til, at 4,4\% var nedlagt $i$ hele landet og knap $7 \%$ på den sjallandske øgruppe. Erland Porsmose har $\mathrm{i}$ afhandlingen: Landsbynedlæggelser og hovedgårdsekspansion på Fyn, Hist. Tidsskr. 1978, s. 437-453, påvist, at Gunnar Olsens tal er for lave.

44. Trap, bd. 26, s. 940.

45. LAÅ, Søgård og Årtoft godser nr. 2.

46. RA, Slesvigske og Holstenske regnskaber før 1580, plov- og frøkenskat af adelen 1543-44.

47. Poul Andersen: Gråsten, s. 28.

48. Trap, bd. 26, s. 950.

49. LAÅ, Søgård og Årtoft godser, pk. 5.

50. RA, Slesvigske og holstenske regnskaber før 1580, plov- og frøkenskat af adelen 1543-44.

51. Sammenlign undersøgelsesprotokollen fra 1709 med en jordebog fra 1721 (LAÅ, gråstenske godser, nr. 153).

52. Werner Buchholz: Bevolkerung und Bevolkerungsstruktur im Amt Gottorf um 1600, ZSHG 1984 s. $97-122$.

53. Se Henning Mathiesens artikel her $\mathrm{i}$ årbogen.

54. Sammenlign Nordborg-jordebogen (RA, film D.69) med undersøgelsesprotokol over Søgård 1709 (LAÅ, Søgård og Årtoft godser nr. 5).

55. LAÅ, Søgård og Årtoft godser nr. 5.

56. Tallet er egentlig ca. 4500 tønder land, men herfra er trukket byen Kiding, der blev nedlagt 1716, da den ellers ville talle med både under hovedgårde og bondegårde.

57. Fæstegodset er opdelt på godser ud fra auktionskataloget 1725 . Skellet mellem øst og vest er foretaget efter herregårdenes bonitet (se nedenfor) og ikke den klassiske administrative opdeling. Til den østlige del regnes alt godset på Sundeved, alt godset i Adsbøl-Gråsten og Rinkenæs sogne, samt Kværs sogn bortset fra Tørsbøl og Felsted sogn bortset fra Nørballe og Felstedskov.

58. Hovedgårdene udgjorde $9 \%$ af kongerigets dyrkede jord. Langt de fleste af dem fandtes på det private gods, der ialt tegnede sig for $63 \%$ af jorden. Heraf kan herregårdene altså maksimalt have udgjort en syvendedel. Se Det danske Landbrugs historie, bd. 2., Kbh. 1988, s. 192.

59. Uwe Bonsen: Die Entwicklung des Siedlungsbildes und der Agrarstruktur der Landschaft Schwansen vom Mittelalter bis zur Gegenwart, Kiel 1966, s. 175f. Ifølge Bonsen var herregårdsmarkerne næsten dobbelt så store som bondejorden, men det var inklusiv skov.

60. LAA, Gråstenske godser pk. 153.

61. Se Henrik Pedersen: De danske landbrug, Kbh. 1928. Normalt måler man kongerigske gårde i hartkorn, der giver et bedre billede af deres produktive værdi. Da hartkornstallene ikke kendes fra Senderjylland, er det valgt at se på arealet $i$ stedet.

62. Wolfgang Prange: Die Anfonge der grossen Agrarreformen in Schleswig-Holstein, Neumünster 1971, s. 386.

63. Peter Kr. Iversen: Hollænderier i Sønderjylland i 1600- og 1700-årene, SJy Årb, 1992, s.73-111.

64. 1715: RA, Rentekammerets tyske sekretariat, ekstraskattekommissioner, G.74, taksationer af ridderskabets og prælaternes undersåtter; 1725a og 1725b: auktionskaloget, LAÅ, Søgård og Årtoft godser pk. 5; 1740: Peter Kr. Iversen i SJy Årb 1992.

65. Heri ikke inkluderet Kiding.

66. Trap, bd. 26. s. 1001 .

67. Foruden auktionskataloget giver jordebogen fra 1721 (LA£, Gråstenske godser, pk. 153) en oversigt over hele godskompleksets indtægter. Desuden findes regnskaber fra de 5 godser, der kom under hertugen af Augustenborg fra 1740'erne (LAÅ, Gråstenske godser, pk. 196) og Søgård-Årtoft fra 1726 og frem (LA, Søgård og Årtoft godser, pk. 46ff). 
68. Bobé, anf. arb. bd. 6, s. 60.

69. LAS, Abt. 65.1 nr. 526.

70. Hugo Matthiessen: En greve. Jørgen Scheel til grevskabet Scheel stamhuset Gl. Estrup samt Sostrup (1768-1825), Kbh. 1954, s. 13; Carsten Porskrog Rasmussen: „Fra Grenå til Viborg på egen jord« - Gammel Estrup som godscentrum, i: Gammel Estrup, udg. af Randers Amts Historiske Samfund 1993, s. 109-33.

71. Bobé, anf.arb. bd. 6, s. 53 og 61 . 